دراسة إقتصادية لدور البنك الزراعي المصري في تمويل الأنثطة الزراعية في محافظة أسوان

$$
\text { عبد العاطي محمد محمود علي } 1
$$

السنوى حوالي 910، 896، 468، 3786، 376 ألف جنيه. تمثل

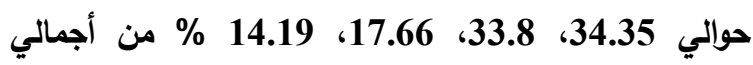
القروض النباتية في محافظة أسوان والبالغ حوالي 2.65 مليون جنيه لكل منها على الترتيب.

3- بدراسة المؤشرات الاقتصادية والإنتمانية للقروض النباتية الممنوحة لمحصول القصب في محافظة أسوان خلال الفترة (2020-2005) بلغ معدل التغير السنوى لكل من التكاليف

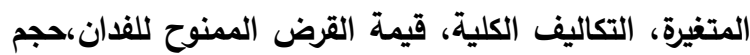

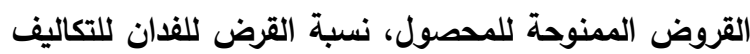
المتغيرة، التكاليف الإتتمانية، صافي العائد الفاني حوالي لاني ،(5.23-) 0.83 6.04، 11.21 6.15، 9.39 \% بينما بلغ المتوسط السنوى حوالي 13.4.04، 10.07، 13.3، 8.4، (2.6 مليون)، 5.7 ألف جنية لكل منها على الترتيب، بينما بلغ للتكاليف الإتتمانية حوالي 420 (16.3 جنية، وأخيرأبلغ لنسبة تغطية القرض للتكاليف المتغيرة حوالئ 0.84\%، وبلخ العائد على الجنيه المستثر حوالي888\%. 4- بلغ معدل التغير السنوى لقروض المشروعات الاستثمارية لإنتاج اللحوم الحمراء بمراكز أدفو، كوم أمبو، نصر النوبة النوبة،

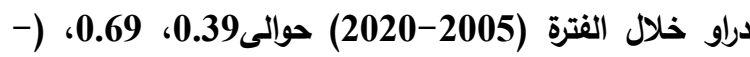
0.18)، 0.36 \% بينما بلغ المتوسط السنوى حوالي 919،

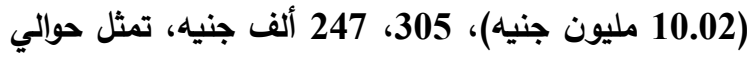
36.89، 40.95، 12.25، 9.91 \% من أجمالي القروض النباتية في محافظة أسوان والبالغ حوالي 2.49 مليون جنيه لكل منها على الترتيب.

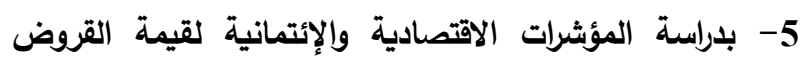
المنوحة لأنواع ماشية التسمين للمشروعات الاستثمارية

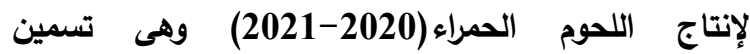

$$
\text { الملخص العربى }
$$

أستهاف البحث تحقيق مجموعة من الأهداف في محافظة أسوان خلال فترة الدراسة (2005-2020)، هي دراسة المؤشرات الاقتصادية لتصنيف إجمالي القروض الزراعية، تطور وكفاءة الإتتمان الزراعي لكل من قروض الانتاج النباتي ،مشروعات التهاتية

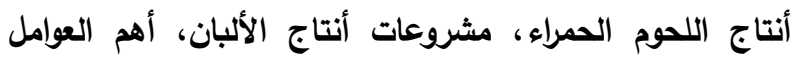

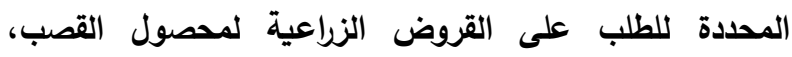

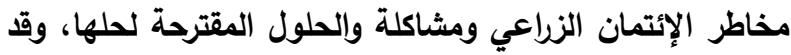

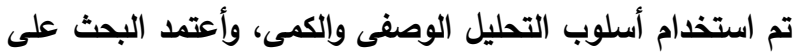

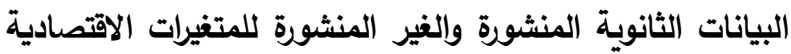

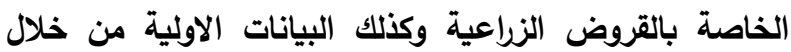
عينة عشوائية تم أخييارها بمركزي أدفو وكوم أمبو وبلغ إجمالي الإلية أعداد مزارعي العينة البحثية حوالي 95 مزراع. وقد توصلت الدارسة إلى النتائج الأتية:

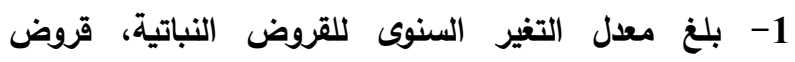

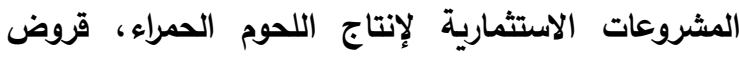

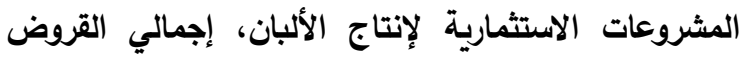

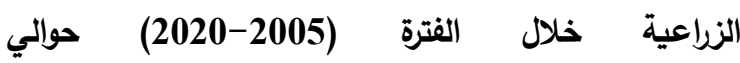
0.83، 0.44، 9.34، 1.55 \% بينما بلغ المتوسط السنوى حوالي 2.65، 0.63، 0.49، 0.601 مليون جنيه. تمثل حوالي 46.16، 43.38، 10.46 \% من متوسط إجمالي القروض الززاعية في محافظة أسوان والبالغ حوالي 5.74 مليون جنيه لكل منها على الترتيب. 2- بلغ معدل التغير السنوى للقروض النباتية بمراكز أدفو، كوم

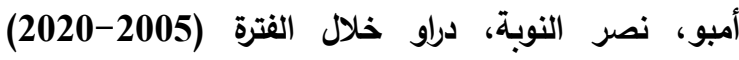

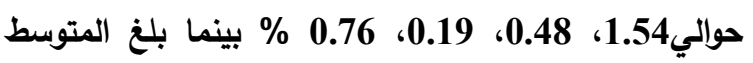


وأنة بزيادة التكاليف المتغيرة، نسبة تغطية القرض للتكاليف

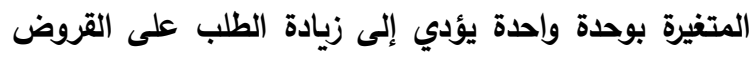
بنحو 0.565 ، 0102.72 وحدة على الترتيب، كما تبين وجود

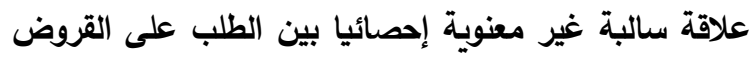

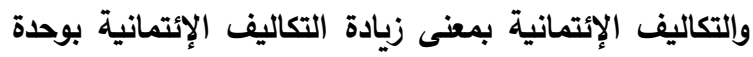
واحدة تؤدي إلى انخفاض الطلب على القروض بمقدار 0.16 وحدة. 9- بلراسة المشكلات الاقتصادية والإئتمانية التى تواجه المزارعين في محافظة أسوان تبين أن أهمها هى ضرورة

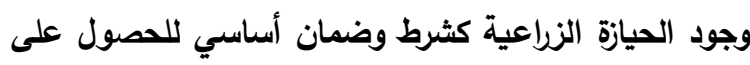
القرض، عدم صرف القروض فى صورة عينية والاكتفاء بالصرف النقدى فقط، عدم صرف القروض إلا بعد سداد

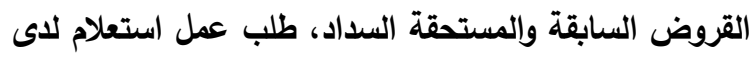
البنك المركزى عن صاحب القرض، تعقيد الشروط والاجراءات للحصول على القرض وكثرة الضمانات، عدم كفاية قيمة القرض للنشاط الإنتاجى المقرر عملة، كما تبين أن أهم أهم

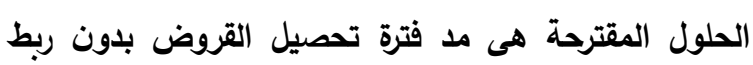
غرامات تاخير أو زيادة معدل الفائدة وأعطاء مهلة للزارع

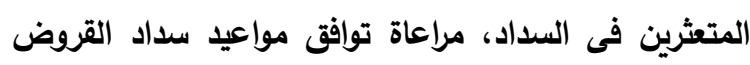
مع مواعيد حصاد المحاصيل وتسويق المنتجات، تقديم وصرف القروض العينية مثل الأسمدة والتقاوي والمبيدات لضمان جودتها وكفايتها، تعديل قيمة القرض سنويا لكل

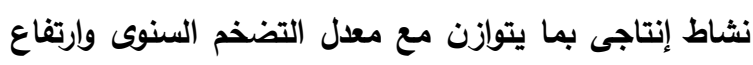

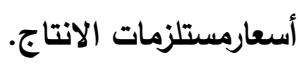
الكلمات المفتاحية: البنك الزراعي المصري، أسوان، الانتاج

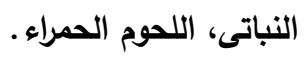

\section{المقدمة}

تواجه التتمية الاقتصادية الزراعية في مصر بصفة عامة وفي محافظة أسوان بصفة خاصة عدد من المشاكل والمعوقات والتى يعتبر ندرة رأس المال المزرعي المتاح لاى لدي المزارع من أهمها حيث يعتبرعنصر رأس المال بصورة رأبرة المختلفة أحد أهم العناصر الإنتاجية الهامة وذلك لتحقيق التتمية الزراعية الافقة والرأسسة، والتي تحتاج إلى تكاليف الإنتاه
الفريزيان، الخليط، البلدى بلغت نسبة تفطية قيمة القرض

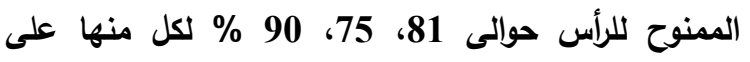
الترتيب، بينما بلغ صافي العائد حوالي 11.2، ألف جنيه للرأس، بلغ العائد على الجنيه المستثمر حوالي 93، 87 ، 1.04 \% لكل منها على الترتيب. 6- بلغ معدل التغير السنوى لقروض المشروعات الاستثمارية

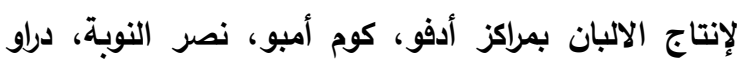
خلال الفترة (2005- 2020) حوالي 8.73، 10.92،

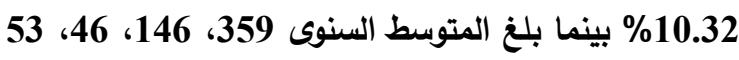
ألف جنيه، تمثل حوالي 59.73، من أجمالي القروض النباتية في محافظة أسوان والبالغ حوالي 601 ألف جنية مليون جنيه لكل منها على الترتيب.

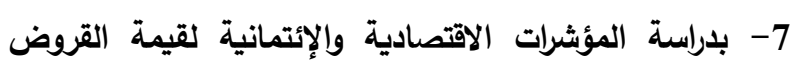

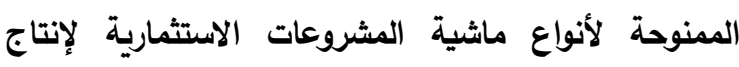

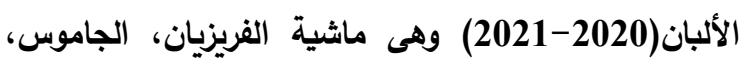

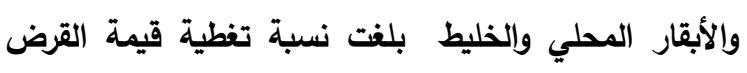

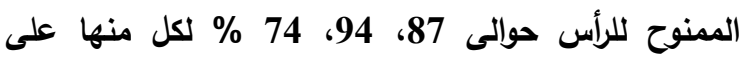
الترتيب، بينما بلغ صافي العائد حوالي 11.1، ألف جنيه للرأس، بلغ العائد على الجنيه المستثمر حوالي 2.7، 2.53، 2.57 \% لكل منها على الترتيب. 8- برراسة العوامل المؤثرة على الطلب على القروض لمحصول

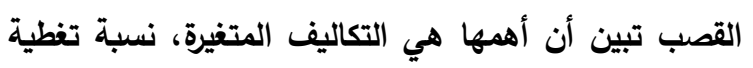

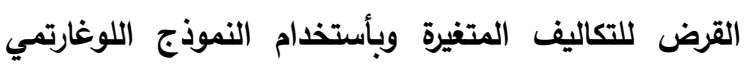

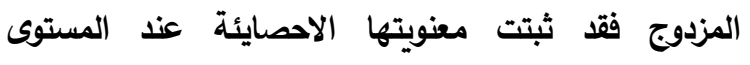

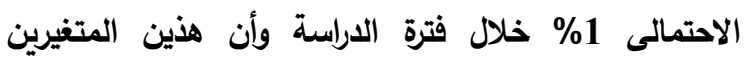
يفسران حوالى 99\% من التغيرات في قيمة القروض الفدانية

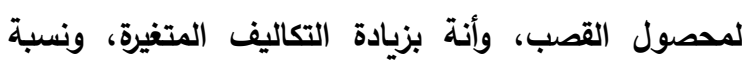
التغطية بنسبة 10\% تؤدي ذلك إلى زيادة الطلب على بلى

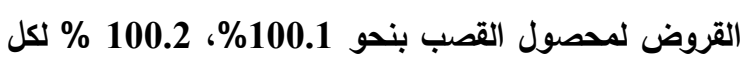
منها على الترتيب، بينما تبين من نتائج التقددير الإحصائي

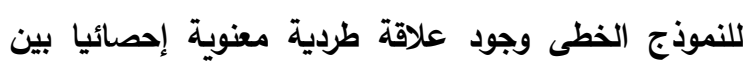
التكاليف المتغيرة س1، نسبة تغطية القرض للتكاليف

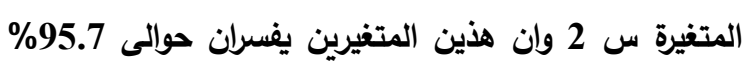
من التغيرات في قيمة القروض الفدانية لمحصول القصب 
الذاتي للعمليات الإنتاجية وهذا ما يتطلب توفير مصادر

للتمويل الزراعي حيث يعتبر رأس المال أحد أهم عناصر

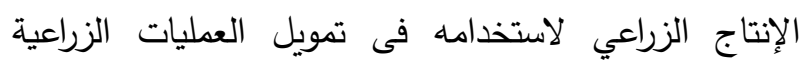

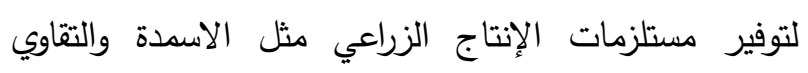

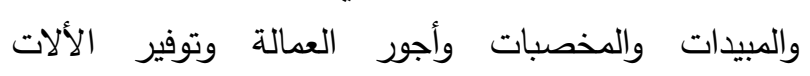

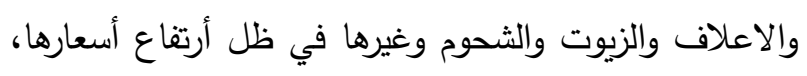
ومن هنا تأتي أهمية وضرورة توفير رأس المال المزرعي المتاح لاى المزارعين للعمل على رفع متوسط الإنتاجية الفدانية.

\section{اهداف البحث}

يهدف البحث الى دراسة مجموعة من الإهداف الاقتصادية والإنتمانية والتي تتمثل في:

أولا: دراسة المؤشرات الاقتصادية لتصنيف إجمالي القروض

$$
\text { الزراعية في محافظة أسوان. }
$$

ثانيا: دراسة تطور وكفاءة الإئتمان الزراعي لكل من قروض الإنتاج النباتي، ومشروعات أنتاج اللحوم الحمراء وإنتاج الألبان بمحافظة أسوان.

ثالثا: دراسة أهم العوامل المحددة للطلب على القروض الممنوحة لمحصول القصب والمؤشرات الإيتمانية للعوائد على أستثمارات القروض في محافظة أسوان. رابعا: دراسة مخاطر الإئتمان الزراعي والمشكلات التى تواجه المزاعين والحلول المقترحة فى محافظة أسوان.

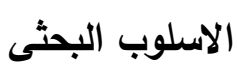

لتحقيق أهداف البحث فقد تم أستخدام الإساليب الإحصائية الوصفية والكمية من خلال دراسة تطور مختلف الفيق أنواع القروض الزراعية الممنوحة من البنك الزراعي المصري

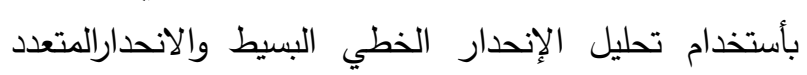
لدراسة أهم العوامل المحددة للطلب على القروض النباتية والمتوسطات الحسابية والنسب المئوية والانحراف المعياري والمتوسط الهندسي وقد تم الاعتماد أيضا على مجموعة من
إنتاجية مرتفعة، وهذا ما يؤكد الدور المحوري لرأس المال

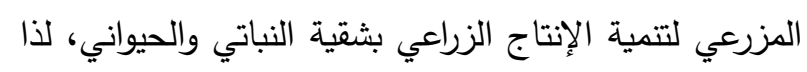

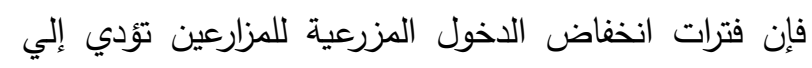

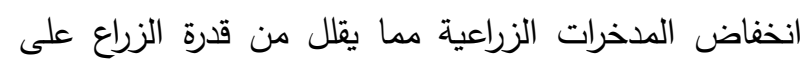
التمويل الذاتي للعمليات الزراعية وهذا ما يستوجب ضرورة توفير مصادر أخرى للتمويل الزراعي لكي يستطيع الزراع

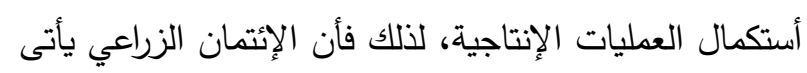

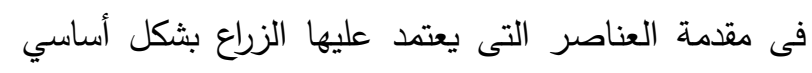

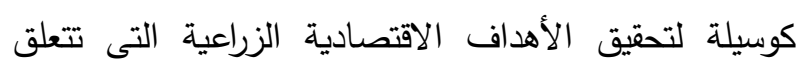
بزيادة دخل الزارع وتحسين مستوى المعيشة ودفع عجلة التتمية الزراعية، ويؤدي الإئتمان الزراعي دورا هاما فى حل عدد كبير من المشكلات التى تواجه الزراع بصفة خاصة صغارهم كما أن حاجة التمويل الزراعي تأتى إلى الإنتاج والاستهلاك فى القطاع الزراعي المتواصل طوال العام وكما أن الإنتاج الزراعي لا يتحقق إلا فى مواسم الحصاد وهو ما يعرف بموسمية الاخل الزراعي. ويعتبر البنك الزراعي

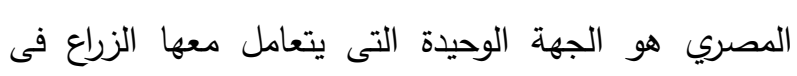
سبيل الحصول على القروض الزراعية اللازمة للعمليات الإنتاجية الزراعية فى صورة سلف زراعية قصيرة الأجل للمحاصيل الزراعية أو سلف زراعية متوسط الأجل تقدم

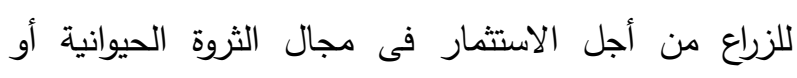
الحصول على ألات زراعية ويتكون الزمام الإدارى لمحافظة أسوان من خمسة مراكز رئيسية هى أدفو، كوم امبو، نصر

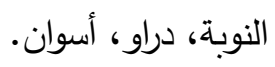

\section{المشكلة البحثيه}

تتمثل المشكلة البحثيه في محافظة أسوان فى مجال الإئتمان الزراعي فى انخفاض الدخل المزرعي للزراع

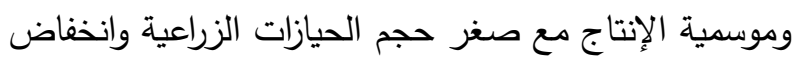

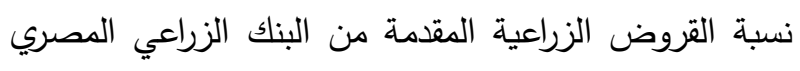

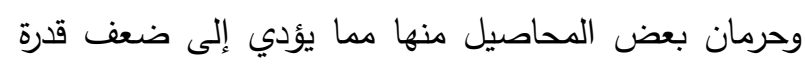
الزراع على الادخار وصعوبة توفير ايه مبالغ مالية للتمويل 
محافظة أسوان مثل البنك الزراعي المصري، مديرية الزراعة

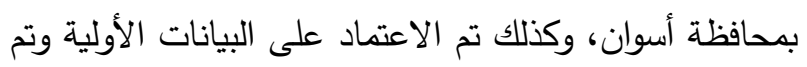

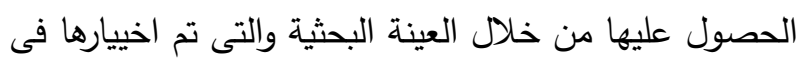

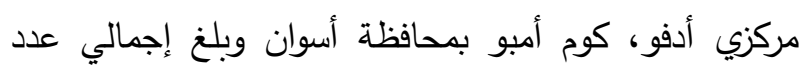
أفرادها حوالى 95 مزارع موزعة على انلى ثلاثة أنشطة أنتاجية

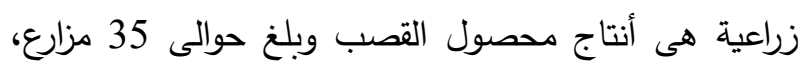

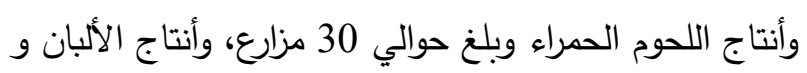
بلغ حوالى 30 مزارع وقد تحدد الددى الزمني لجمع بيانات البحث من شهر يوليو 2020 حتى شهر يونية 2021.

النتائج البحثية والمناقثة

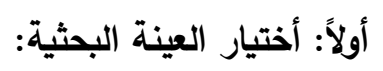

يتاول هذا الجزء من البحث أختيار العينة البحثية

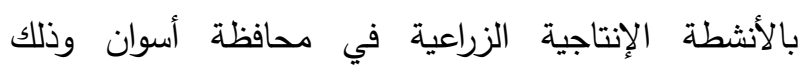

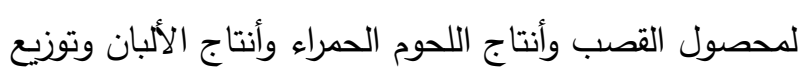
العينة البحثية على المراكز الإدراية المختارة وكذلك الجمعيات التعاونية الزراعية.

وقد تبين من البيانات الواردة بالجدول (1) بدراسة الأهمية

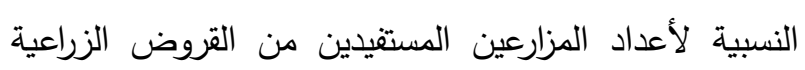
لمحصول القصب فى محافظة أسوان عام (2020-2021) أنها بلغت في مراكز أدفو، كوم أمبو، نصر النوان النوبة، دراو 32 ،

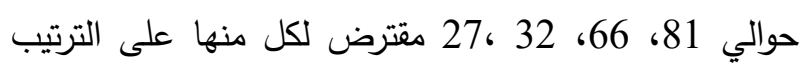

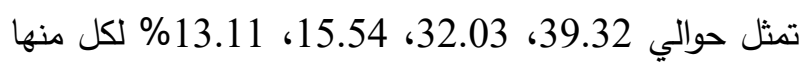
على الترتيب من أجمالي أعداد المزارعين المستفيدين من

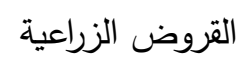

الدقاييس الإحصائية المتعلقة بقياس كفاءة الإتتمان الزراعي وهى:

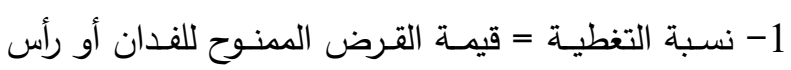
الماشية (التسمين أو الألبان) / التكاليف المتغية.

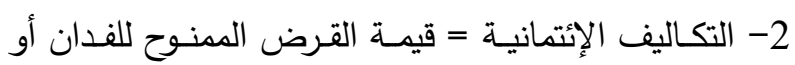
رأس الماشية * معدل الفائدة.

3- متوسط التكاليف التى لـ يقدم لها قروض = متوسط التكاليف المتغيرة - قيمة القرض الممنوح للفدان أو رأس له لهن

$$
\text { الماثية (التسمين أو الألبان). }
$$

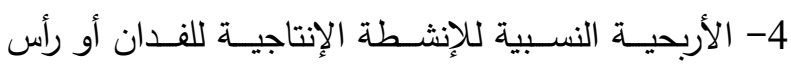

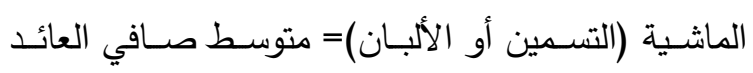

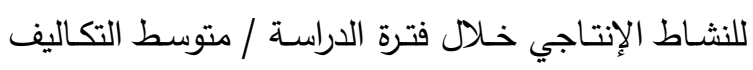
الكلية للنثاط الإنتاجي خلال فترة الدراسة. 5- العائد على الجنيه المستثمر / قرض لكل نثاط إنتاجي= متوســ قيمـة القـرض للنشـاط الإنتـاجي مضــافا إليـهـ

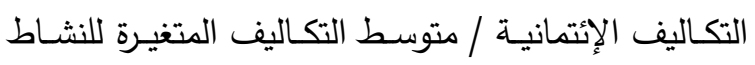
الإنتاجي خلال فترة الدراسة. 6- أعلى حد أدنى= 2 * الانحراف المعياري لصافي العائد للنثاط الإنتاجي.

\section{مصادر البيانات - - مات}

اعتمد البحث على البيانات الثانوية المنشورة وغير

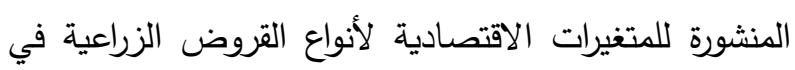

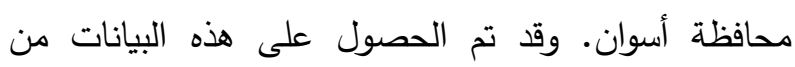

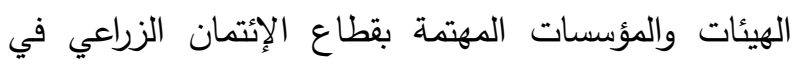


جدول 1. الأهمية النسبية لأعداد المزارعين المستفيدين من القروض النباتية الممنوحة لمحصول القصب فى محافظة أسوان

عام (2021-2020)

\begin{tabular}{|c|c|c|c|c|}
\hline$\%$ & قيمة القروض الممنوحة لمحصول القصب & $\%$ & أعداد المزارعين المستفيدين & المراكز \\
\hline 39.41 & 1135 & 39.32 & 81 & أدفو \\
\hline 32.12 & 925 & 32.03 & 66 & كوم أمبو \\
\hline 15.45 & 445 & 15.54 & 32 & 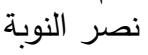 \\
\hline 13.02 & 375 & 13.11 & 27 & 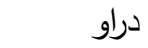 \\
\hline 100 & 2880 & 100 & 206 & 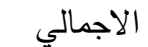 \\
\hline
\end{tabular}

المصدر : جمعت وحسبت من بيانات:

1- البنك الزراعي المصري بمحافظة أسوان، إدارة الإحصاء، بيانات غير منشورة.

2- وزارة الزرعة واستصلاح الاراضي، مديرية الزراعة بمحافظة أسوان، ادارة المحاصيل السكرية، بيانات غير منشورة.

فى حين تبين من البيانات الواردة بالجدول (2) بدراسة

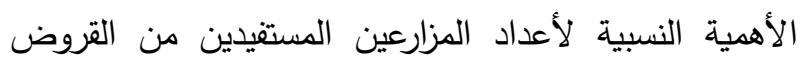
الزراعية الممنوحة للمشروعات الاستثمارية لإنتاج اللحوم الحمراء في محافظة أسوان أنها بلغت فى مراكز أدفو، كوم أمبو، نصر النوبة، دراو حوالي 57، 60، 16، 14 مقترض فئل لكل منها على الترتيب، تمثل حوالي 3ون 38.78، 40.82، 10.88، 9.52 \% لكل منها على الترتيب من أجمالي أعداد المستفيدين من القروض الزراعية لإنتاج اللحوم الحمراء في مني

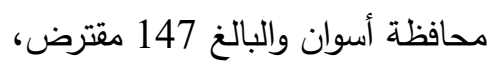

لمحصول القصب في محافظة أسوان والبالغ نحو206 مقروة مقترض، بينما بلغت قيمة القروض الممنوحة لمحصول القصب لمركز أدفو حوالى 1.13 مليون جنيه تمثل حوالي 39.41\% وبلغت حوالي 925، 445، 375 ألف جنيه لكل من مراكز كوم أمبو، نصر النوبة، دراو علي الترتيب تمثل دوال

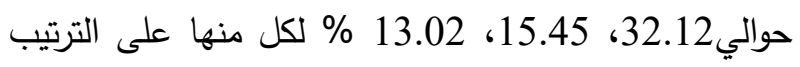
من إجمالي القروض الممنوحة لمحصول القصب في في محافظة أسوان والبالغ نحو 2.88 مليون جنيه.

جدول 2. الأهميـة النسبية لأعداد المـزارعين المستفيدين مـن القروض الممنوحـة للمشـروعات الاسـتثماربة لإنتاج اللحوم الحمراء والألبان في محافظة أسوان عام (2020-2021)

\begin{tabular}{|c|c|c|c|c|c|c|c|c|}
\hline \multicolumn{4}{|c|}{ المشروعات الاستثمارية لإنتاج الآلالبان } & \multicolumn{4}{|c|}{ المشروعات الاستثمارية لإنتاج اللحوم الحمراء } & \multirow[b]{2}{*}{ المركز } \\
\hline$\%$ & قالميمة القروض & $\%$ & المستفيدين & $\%$ & قيمة القروض & $\%$ & المستفيدين & \\
\hline 67.18 & 907 & 53.06 & 26 & 38.84 & 969 & 38.78 & 57 & أدفو \\
\hline 21.41 & 289 & 36.73 & 18 & 40.44 & 1009 & 40.82 & 60 & كوم أمبو \\
\hline 4.52 & 61 & 4.09 & 2 & 10.9 & 272 & 10.88 & 16 & نصر النوبة \\
\hline 6.89 & 93 & 6.12 & 3 & 9.82 & 245 & 9.52 & 14 & 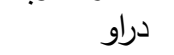 \\
\hline 100 & 1350 & 100 & 49 & 100 & 2495 & 100 & 147 & الاجمالي \\
\hline
\end{tabular}


تمثل حوالي 67.18، 21.41، 4.25، 6.89 \% لكل منها علي الترتيب من إجمالي قيمة القروض الممنوحة لإنتاج الألبان والبالغ نحو 1.35 مليون جنيه.

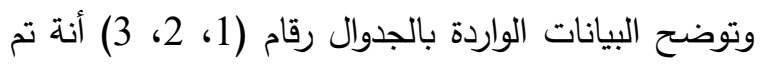

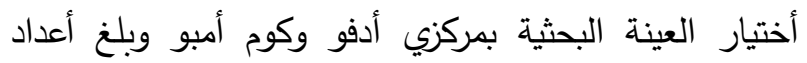
مزارعي محصول القصب بالعينة البحثية حوالي 35 مزارع تمثل حوالي 17\% من إجمالى أعداد المزارعين المستفيدين من القروض لمحصول القصب والبالغ نحو 206 مزارع، وتم توزيع مزارعي العينة على المركزين حيث بلغ حوالي 24، 11

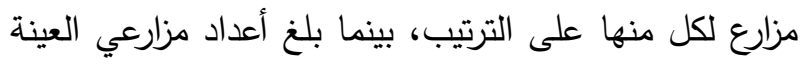

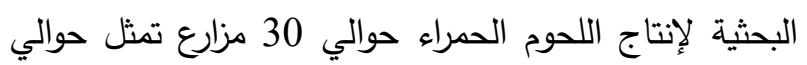

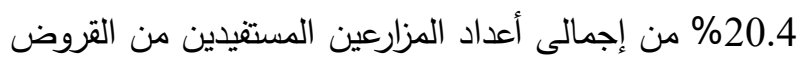

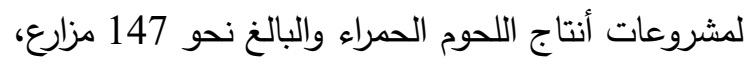

بينما بلغت قيمة القروض بمركز كوم أمبو حوالي 1.09 مليون جنيه تمثل حوالي 40.44\%، وبلغت قيمة القروض كبر بمراكز أدفو، نصر النوبة، دراوحوالي 969، 272، 245 ألف جنيه لكل منها علي الترتيب تمثل حوالي 38.84، 10.9، 9.82\% لكل منها على الترتيب من إجمالي قيمه القروض الممنوحة لإنتاج اللحوم الحمراء بمحافظة أسوان

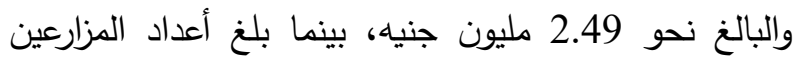

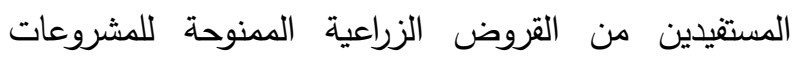
الاستثمارية لإنتاج الألبان حوالي 26، 18، 2، 3 مقترض لكل منها على الترتيب تمثل حوالي 53.06، 35.73، 36.73، 4.09، 6.12 \% لكل منها على الترتيب من إجمالي أعداد المزارعين المستفيدين والبالغ نحو 49 مقترض، بينما بلغت

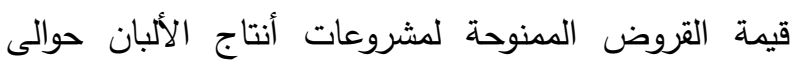
907، 289، 61، 93 ألف جنيه لكل منها على الترتيب،

جدول 3. توزيـع العينـة البحثيـة على المراكز المختـارة للمزارعين المستقيدين مـن القروض الممنوحـة لمحصـول القصب

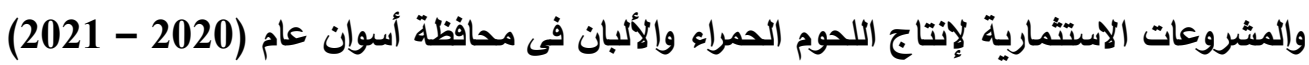

\begin{tabular}{|c|c|c|c|c|c|c|c|c|}
\hline البعارعيد & 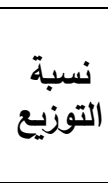 & الهندسي" & $\%$ & (القروضة & $\%$ & ألعداد المزارعين & المراكز & 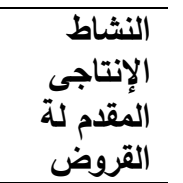 \\
\hline 24 & 67.34 & 303.2 & 55.1 & 1135 & 55.1 & 81 & أدفو & أنتاج \\
\hline 11 & 32.66 & 2470.08 & 44.9 & 925 & 44.9 & 66 & كوم أمبو & محصول \\
\hline 35 & 100 & 450.28 & 100 & 2060 & 100 & 147 & الاجمالى & القصب \\
\hline 15 & 48.85 & 235.01 & 48.99 & 969 & 48.72 & 57 & أدفو & مشروعات \\
\hline 15 & 51.15 & 246.04 & 51.01 & 1009 & 51.28 & 60 & كوم أمبو & أنتاج اللحوم \\
\hline 30 & 100 & 481.05 & 100 & 1978 & 100 & 117 & الاجمالى & الحمراء \\
\hline 20 & 68.04 & 153.56 & 75.83 & 907 & 59.09 & 26 & & \\
\hline 10 & 31.96 & 72.12 & 24.17 & 289 & 40.91 & 18 & كوم أمبو & | مانتبرو | \\
\hline \multirow[t]{6}{*}{30} & 100 & 225.68 & 100 & 1196 & 100 & 44 & الاجمالي & \\
\hline & & \multicolumn{7}{|c|}{ • المتوسط الهندسي = الجذرالنوني لحاصل ضرب أعداد المزارعين المستفيدين من القروض * قيمة القروض الممنوحة. } \\
\hline & & \multicolumn{7}{|c|}{ 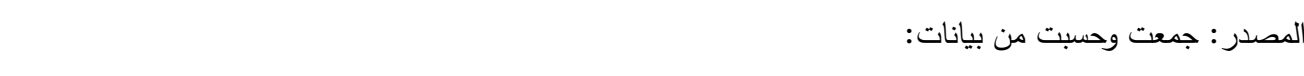 } \\
\hline & & \multicolumn{7}{|c|}{ 1- البنك الزراعي المصري بمحافظة أسوان، إدارة الإحصاء، بيانات غير منشورة. } \\
\hline & & \multicolumn{7}{|c|}{ 2- وزارة الزرعة واستصلاح الاراضي، مديرية الزراعة بحافظة أسوان، ادارة الإنتاج الحيواني، بيانات غير منشورة. } \\
\hline & & \multicolumn{7}{|c|}{ 3- وزارة الزرعة واستصلاح الاراضي، مديرية الزراعة بحافظة أسوان، ادارة المحاصيل السكرية، بيانات غير منشورة. } \\
\hline
\end{tabular}


على جمعيتي العوضلاب والحرايزة وبلغ بكل منها حوالي

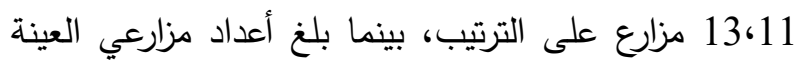

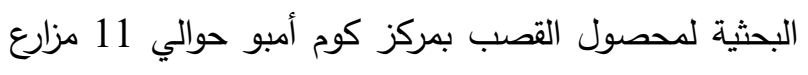

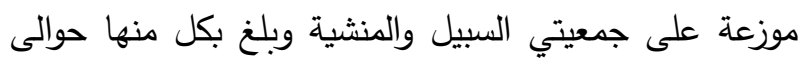

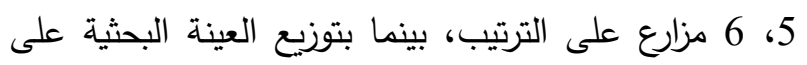

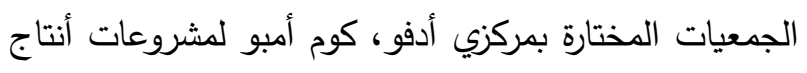

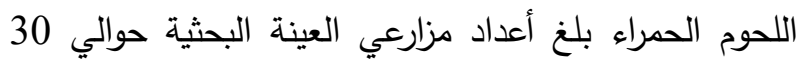

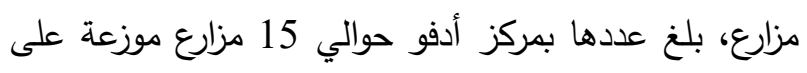

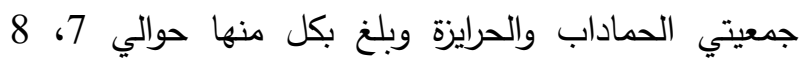
كزارع على الترتيب، بلغ أعداد مزارعي العينة البحثية بمركز

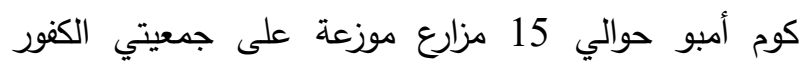

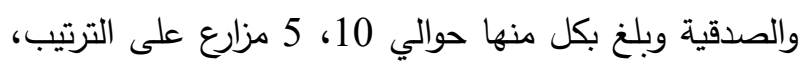
بينما بتوزيع العينة البحثية على الجمعيات المختارة بمركزي

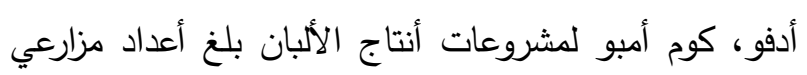

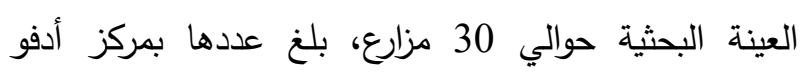

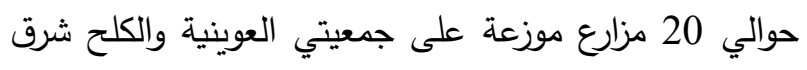

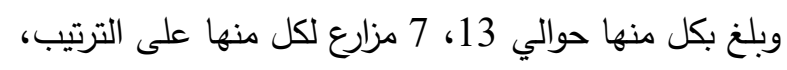

وتم توزيع مزارعي العينة على المركزين حيث بلغ حوالي 15، 15 مزارع لكل منها على الترتيب، بلغ أعداد مزارعي العينة

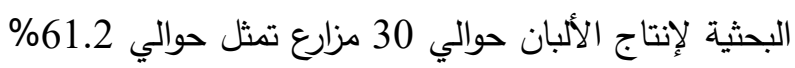

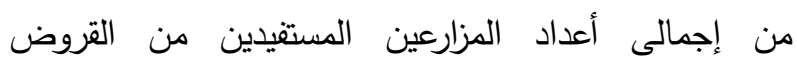

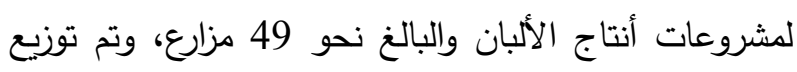

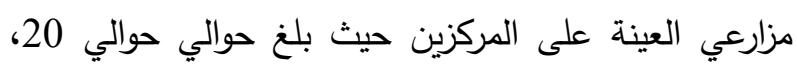

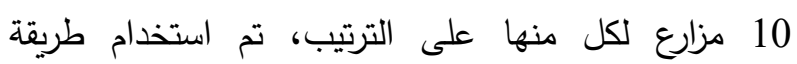

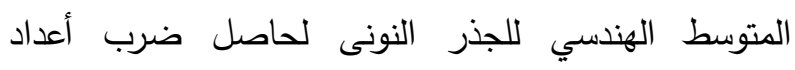

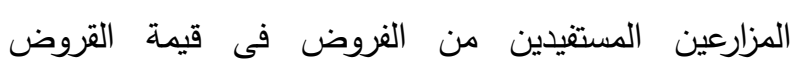
المنوحة وذلك لتوزيع أعداد مزارعي العينة البحثية على فئي المراكز المختارة للعينة البحثية.

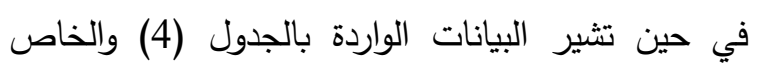
بتوزيع أعداد مزارعي العينة البحثية على الجمعيات المختارة

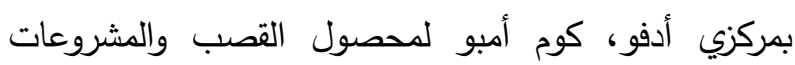

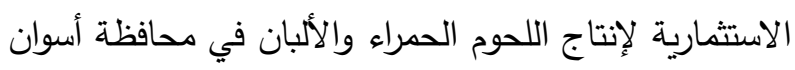

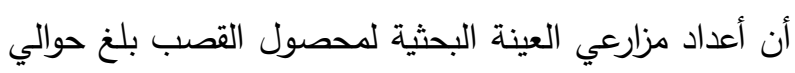
35 مزارع، بلغ عددها بمركز أدفو حوالي 24 مزارع موزعة العيلة

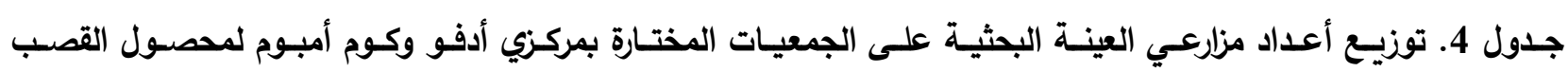
والمشروعات الاستثمارية لإنتاج اللحوام الحمراء والألبان في محافظة أسوان عام الجمات (2020 - 2021)

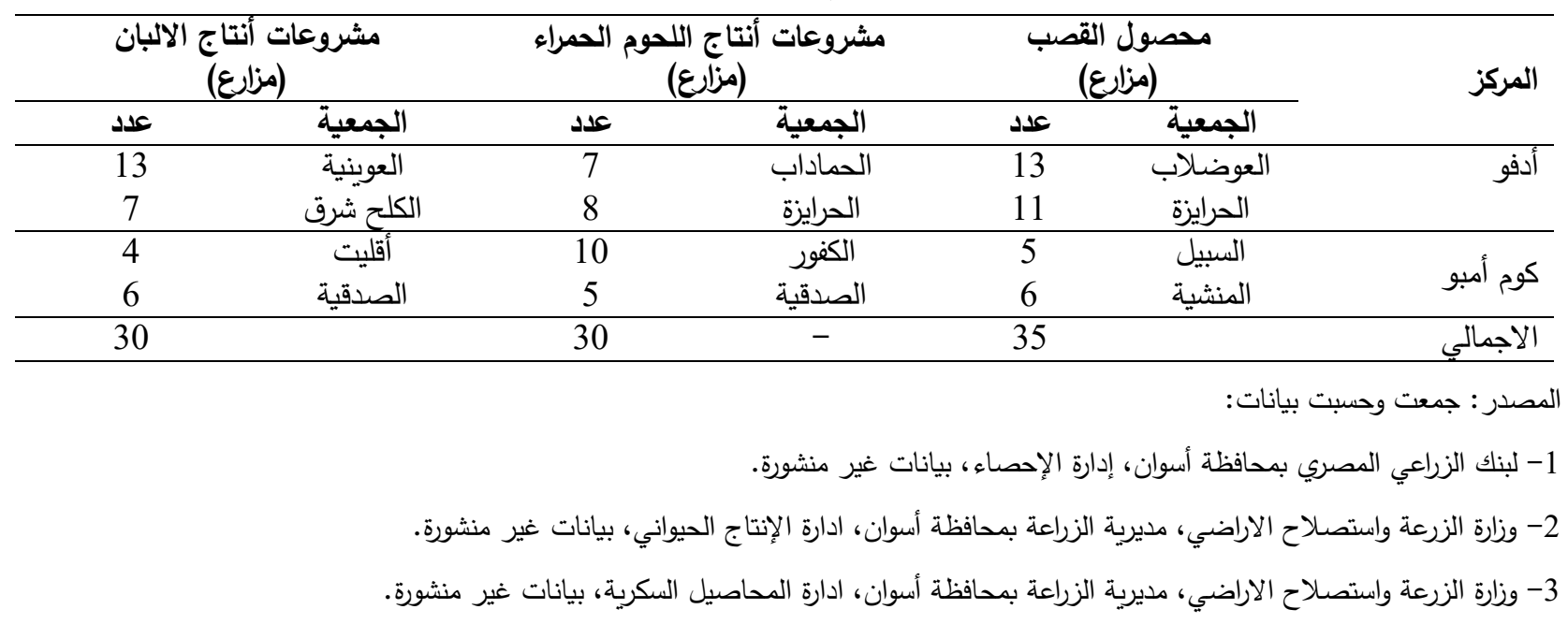


لإنتاج الألبان وهى قروض متوسطة الاجل تمنح إلى خمس

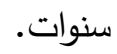

(1) (1) تطور القروض النباتية:

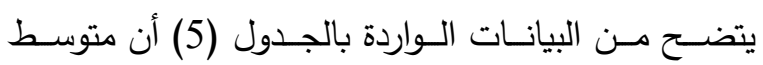

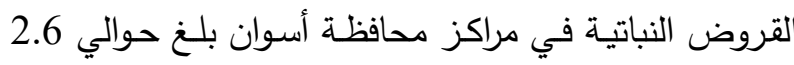
مليون جنيه خلال الفترة (2005 - 2020)، قد تراوحت بين

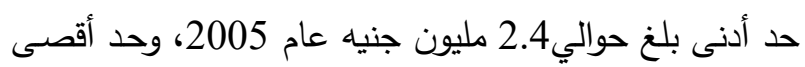

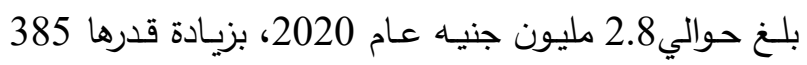
ألف جنيه، تمثل حوالي 15.43 \% من عام 2005. وقلئ وقد تبين من المعادلة المقدرة لتطور الاتجاة الزمنى للقروض النباتية

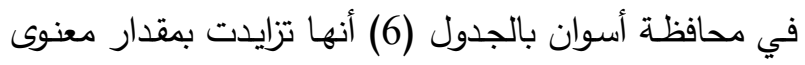

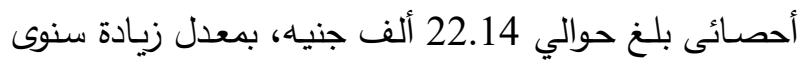
بلغ حوالي 0.83 \% من متوسط القروض النباتية خلال فترة

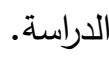

بلغ أعداد مزارعي العينة البحثية بمركز كوم أمبو حوالي 10 مزارع موزعة على جمعيتي أقليت والصدقية وبلغ بكل منها حوالي 4، 6 مزارع لكل منها الترتيب، تم استخدام طريقة المتوسط الهندي للجذر النونى لحاصل ضرب لهرب أعداد

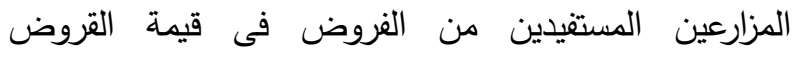
الممنوحة لتوزيع أعداد مزارعي العينة البحثية على الجمعيات المختارة للعينة البحثية.

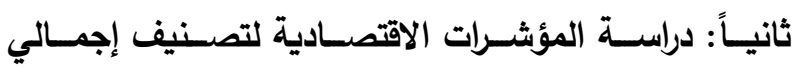
القروض الزراعية في محافظة أسوان: يتــاول هذا الجزء مـن البحث دراسـة إجمـالي القروض

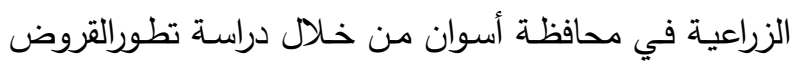

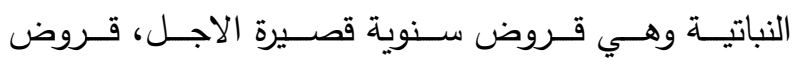
المشروعات الاستثمارية لإنتاج اللحوم الحمراء وهي ايضـا قروض سنوية قصيرة الاجل، قروض المشروعات الاستثمارية

جدول 5. تطور تصنيف إجمالي القروض الزراعية في محافظة أسوان خلال الفترة (2005-2020)

\begin{tabular}{|c|c|c|c|c|c|c|c|}
\hline 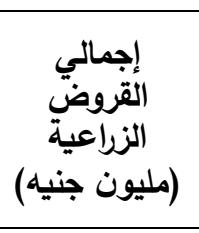 & $\%$ & المشروعات الألاستثماريةية & $\%$ & 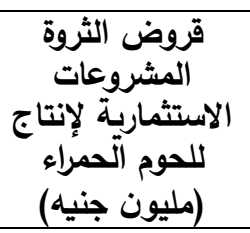 & $\%$ & $\begin{array}{c}\text { (النباتية } \\
\text { (مليون جنيه) }\end{array}$ & السنوات \\
\hline 5189 & 5.69 & 295 & 46.23 & 2399 & 48.08 & 2495 & 2005 \\
\hline 5245 & 5.72 & 300 & 46.04 & 2415 & 48.24 & 2530 & 2006 \\
\hline 5287 & 5.69 & 301 & 45.98 & 2431 & 48.33 & 2555 & 2007 \\
\hline 5354 & 5.77 & 309 & 46.08 & 2467.0 & 48.15 & 2578 & 2008 \\
\hline 5447 & 7.44 & 405 & 44.69 & 2434.0 & 47.88 & 2608 & 2009 \\
\hline 5518 & 8.14 & 449 & 43.46 & 2398.0 & 48.41 & 2671 & 2010 \\
\hline 5512 & 7.78 & 429 & 44.97 & 2479.0 & 47.24 & 2604 & 2011 \\
\hline 5567 & 9.92 & 552 & 44.44 & 2474.0 & 45.64 & 2541 & 2012 \\
\hline 5628 & 10.91 & 614 & 44.40 & 2499.0 & 44.69 & 2515 & 2013 \\
\hline 5838 & 11.73 & 685 & 43.54 & 2542.0 & 44.72 & 2611 & 2014 \\
\hline 6018 & 12.76 & 768 & 42.51 & 2558.0 & 44.73 & 2692 & 2015 \\
\hline 6196 & 15.28 & 947 & 41.25 & 2556.0 & 43.46 & 2693 & 2016 \\
\hline 5726 & 6.34 & 363 & 44.64 & 2556.0 & 49.02 & 2807 & 2017 \\
\hline 6038 & 8.86 & 535 & 44.29 & 2674.0 & 46.85 & 2829 & 2018 \\
\hline 6580 & 19.88 & 1308 & 37.57 & 2472.0 & 42.55 & 2800 & 2019 \\
\hline 6725 & 20.07 & 1350 & 37.10 & 2495.0 & 42.83 & 2880 & 2020 \\
\hline 5742 & 10.46 & 601 & 43.38 & 2491 & 46.16 & 2651 & المتوسط \\
\hline
\end{tabular}

المصدر : جمعت وحسبت من بيانات : البنك الزراعي المصري بمحافظة أسوان، إدارة الإحصاء، بيانات غير منشورة. 
معنوى أحصائي بلغ حوالي 11.063 ألف جنيه، بمعدل زيادة سنوى بلغ حوالي 0.44 \% من متوسط قروض المشروعات

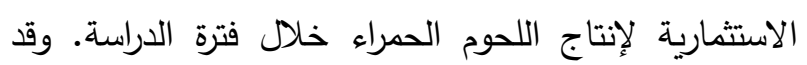
بلغت الأهمية النسبية لقروض المشروعات الاستثمارية لإنتاج

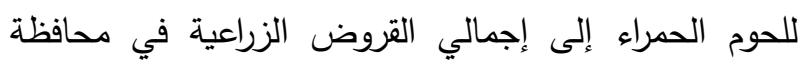
أسوان حوالي 46.2\% عام 2005 انخفضت إلى حوالي الني

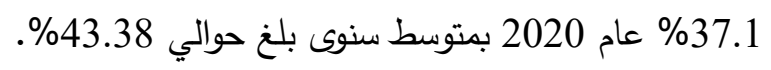
(3) تطور قروض المشروعات الاستثمارية لإنتاج الألبان:

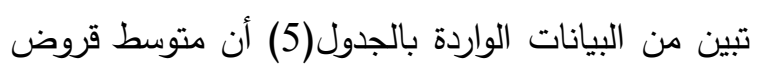
المشروعات الاستثمارية لإنتاج الألبان في محافظة أسوان بلغ الغان

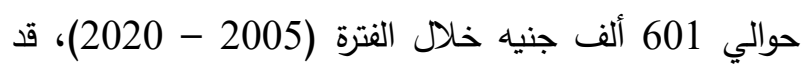

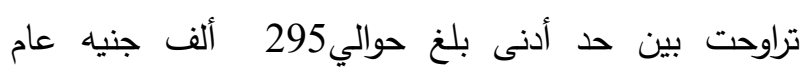

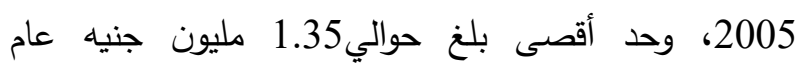

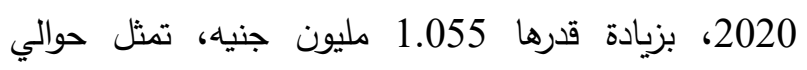
357.62
وقد بلغت الأهميـة النسبية للقروض النباتيـة إلى إجمـالي

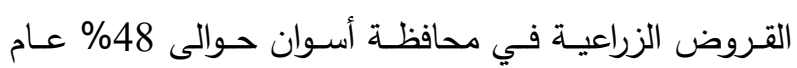
2005 انخفضت إلى حوالي 42.8\% عام 2020 بمتوسط سنوى بلغ حوالي 46.18\%. (2) تطور قروض المشروعات الاستثمارية لإنتاج اللحوم

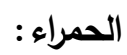

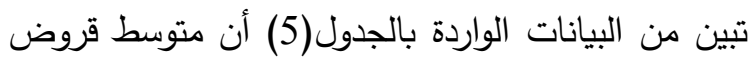
المشروعات الاستثمارية لإنتاج اللحوم الحمراء في محافظة الدانة أسوان بلغ حوالي 2.4 مليون جنية خلال الفترة (2005-

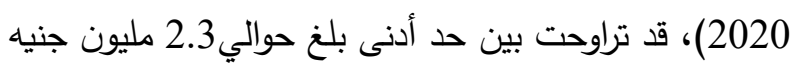

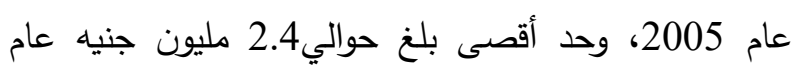

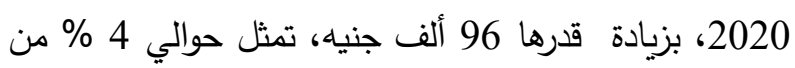
عام 2005. وقد تبين من الدعادلة المقدرة لتطور الاتجاة

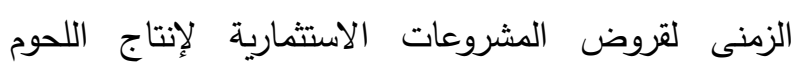

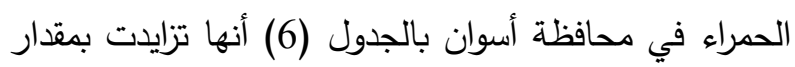

جدول 6. نتائج التقدير الاحصائي لمعادلات الاتجاة الزمنى لتصنيف إجمالي القروض الزراعية في محافظة أسوان خلال

الفترة (2000-2020)

\begin{tabular}{|c|c|c|c|c|c|}
\hline $\begin{array}{c}\text { معدل التغير } \\
\text { \% }\end{array}$ & المتوسط & ف & 2 & المعادلة & المتغيرات التابعة \\
\hline 0.83 & 2651 & " 40.490 & 0.743 & 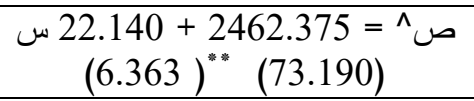 & القروض النباتية (مليون جنيه) \\
\hline 0.44 & 2491 & ""15.093 & 0.519 & $\begin{array}{c}11.063+2396.525=\wedge \\
(3.885)^{* * *}(87.034)\end{array}$ & $\begin{array}{r}\text { قروض المشروعات الاستثمارية للحوم الحمراء } \\
\text { الإنيون جنيه) }\end{array}$ \\
\hline 9.34 & 601 & 22.889 & 0.621 & $\begin{array}{c}56.188+123.025=\wedge \text { ص }{ }^{*} \text { ص }(4.785)^{* *}(1.084)\end{array}$ & 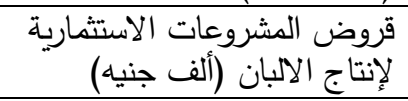 \\
\hline 1.55 & 5742 & "80.050 & 0.851 & 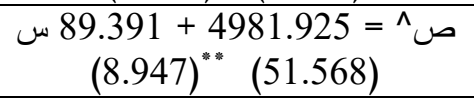 & $\begin{array}{r}\text { إجمالى القروض الزراعية) } \\
\text { (مليون جنيه) }\end{array}$ \\
\hline & & \multicolumn{4}{|c|}{ 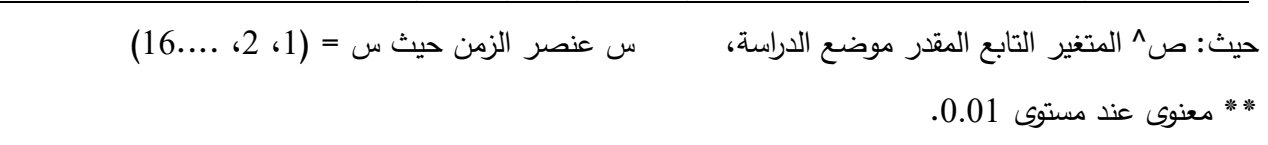 } \\
\hline
\end{tabular}


النباتية في محافظة أسوان وكذلك محصول القدح حيث أنة لم

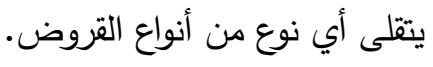
دراسة القروض النباتية في مراكز محافظة أسوان:

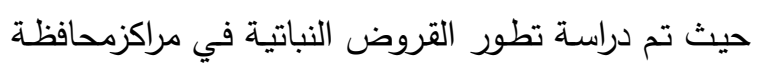

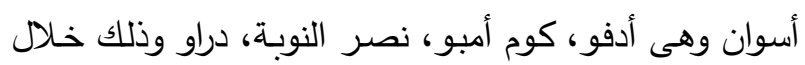

$$
\text { الفترة (2005-2020). }
$$

تطور القروض النباتية بمركز ادفو:

تبين من البيانات الواردة بالجدول (7) أن متوسط لبرد القروض النباتية في مركز أدفو بلغ حوالي 910 ألف جنيه النيه

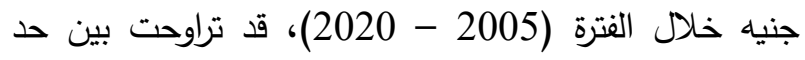
أدنى بلغ حوالي 833 ألف جنيه عام 2005، وحد أقصى بلغ

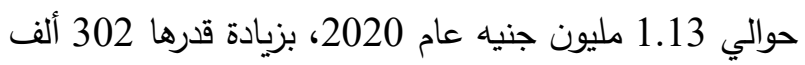

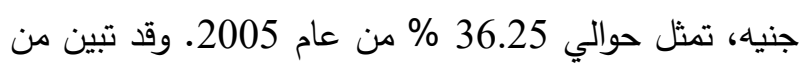

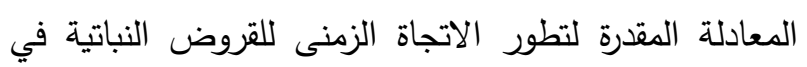

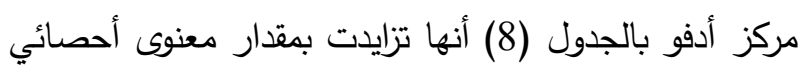

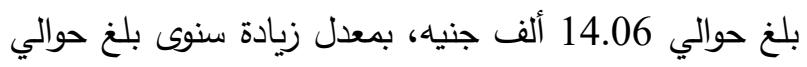
1.54 \% من متوسط القروض النباتية خلال فترة الدراسة. تطور القروض النباتية بمركز كوم أمبو:

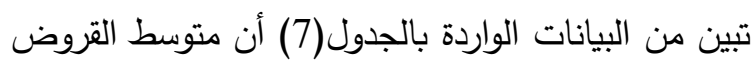
النباتية في مركز كوم أمبو بلغ حوالي 896 ألف جنيه خلادل الجدال الفترة (2005 - 2020)، قد تراوحت بين حد أدنى بلغ حوالي 851 ألف جنيه عام 2005، وحد أقصى بلغ حوالي

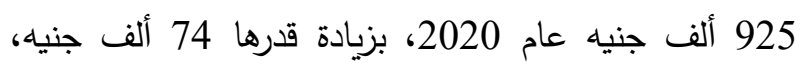
تمثل حوالي 8.69 \% من عام 2005. وقد تبين من المعادلة

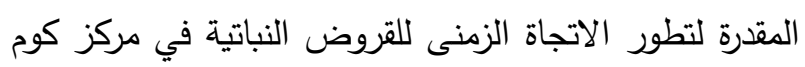

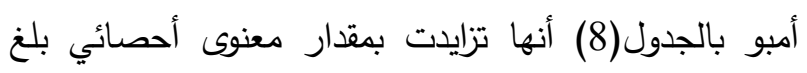
حوالي 4.32 ألف جنيه، بمعدل زيادة سنوى بلغ حوالي بنالي 0.48 \% من متوسط القروض النباتية خلال فترة الدراسة.
وقد تبين من المعادلة المقدرة لتطور الاتجاة الزمنى لقروض

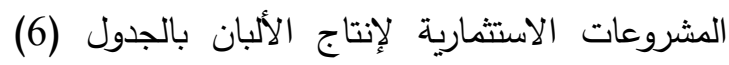
تزايدت بمقدار معنوى أحصائي بلغ حوالي 56.18 ألف الفئ

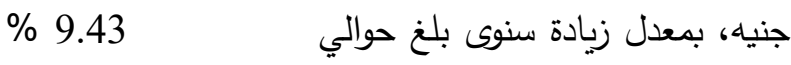

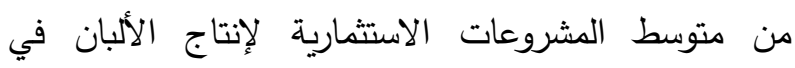

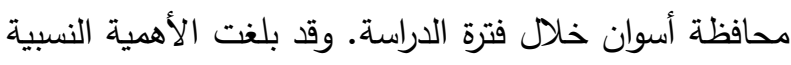

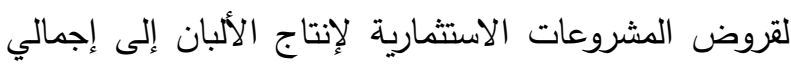

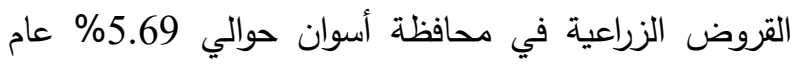
2005 تزايدت إلى حوالي 20.07\% عام 2020 بمتوسط سنوى بلغ حوالي 10.46\% ترابت الى حوالي (4) تطور إجمالي القروض الزراعية: تبين من البيانات الواردة بالجدول (5) أن متوسط إجمالي القروض الزراعية في محافظة أسوان بلغ حوالي 5.74 مليون

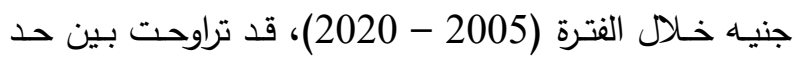

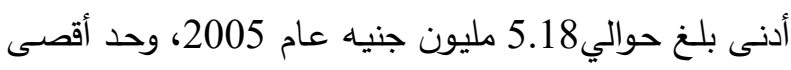

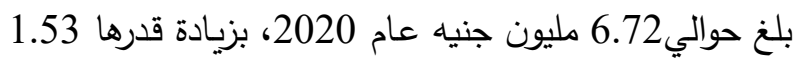

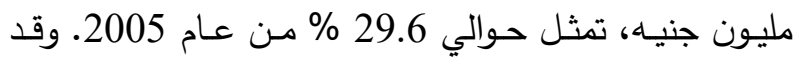

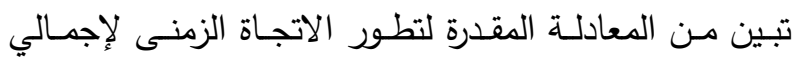

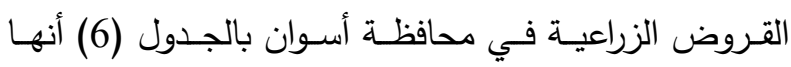

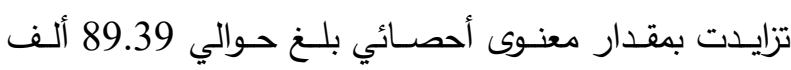

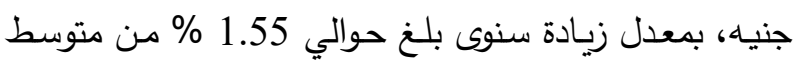
القروض النباتية خلال فترة الدراسة. ثالثا: دراسـة تطوروكفـاءة القروض النباتيـة فـى محافظـة

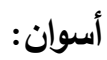
يتتاول هذا الجزء من البحث دراسة تطور القروض النباتية في مراكز محافظة أسوان وكذلك الكفاءة الإتتمانية

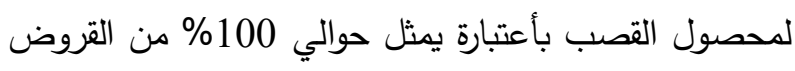



عبد العاطي محمد محمود علي: دراسة إقتصادية لدور البنك الزراعي المصري في تمويل الأنشطة الزراعية ...

جدول 7. تطور إجمالي القروض النباتية في مراكز محافظة أسوان خلال الفترة (2005 - 2020)

\begin{tabular}{|c|c|c|c|c|c|}
\hline \multirow{2}{*}{ إجمالي القروض النباتية } & \multicolumn{4}{|c|}{ المراكز } & \multirow[b]{2}{*}{ السنوات } \\
\hline & (ألف دراويه) & نصب النية' & (ألفوم جنيه) & (ألف جنيه) & \\
\hline 2495 & 355 & 456 & 851 & 833 & 2005 \\
\hline 2530 & 363 & 455 & 862 & 850 & 2006 \\
\hline 2555 & 374 & 462 & 865 & 854 & 2007 \\
\hline 2578 & 374 & 465 & 885 & 854 & 2008 \\
\hline 2608 & 360 & 478 & 895 & 875 & 2009 \\
\hline 2671 & 378 & 481 & 916 & 896 & 2010 \\
\hline 2604 & 358 & 454 & 906 & 886 & 2011 \\
\hline 2541 & 348 & 447 & 876 & 870 & 2012 \\
\hline 2515 & 353 & 440 & 869 & 853 & 2013 \\
\hline 2611 & 374 & 468 & 894 & 875 & 2014 \\
\hline 2692 & 382 & 471 & 932 & 907 & 2015 \\
\hline 2693 & 397 & 485 & 896 & 915 & 2016 \\
\hline 2807 & 387 & 587 & 906 & 927 & 2017 \\
\hline 2829 & 471 & 456 & 949 & 953 & 2018 \\
\hline 2800 & 372 & 433 & 914 & 1081 & 2019 \\
\hline 2880 & 375 & 445 & 925 & 1135 & 2020 \\
\hline 2651 & 376 & 468 & 896 & 910 & المتوسط \\
\hline
\end{tabular}

تطور القروض النباتية بمركز دراو:

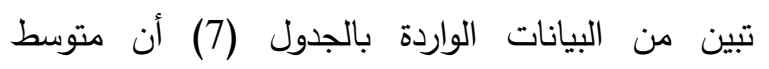
القروض النباتية في مركزدراو بلغ حوالى 376 ألف جنيات النيه خلال الفترة (2005 - 2020)، قد تراوحت بين حد حدر أدنى بلغ حوالي 355 ألف جنيه عام 2005، وحد أقصى بلغ حوالي 375 ألف جنيه عام 2020، بزيادة قدرها 20 ألف جنيه، تمثل حوالي 5.63 \% من عام 2005. وقد تبين من المعادلة

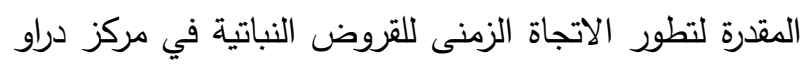

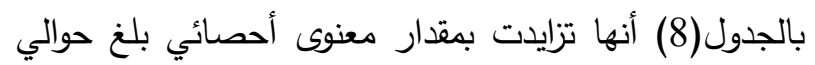

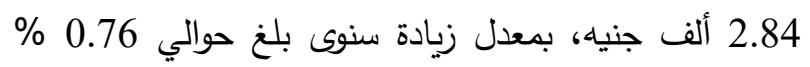
من متوسط القروض النباتية خلال فترة الدراسة.
تطور القروض النباتية بمركز نصر النوبة:

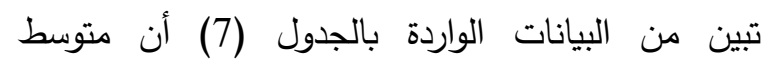

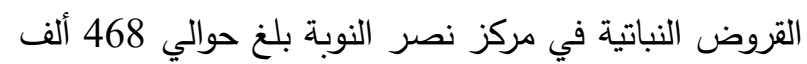
جنيه خلال الفترة (2005 - 2020)، قد تراوحت بين حد في

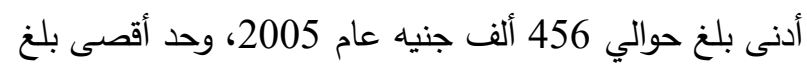
حوالي 481 ألف جنيه عام 2010، بزيادة قدرها 25 ألف والف جنيه، تمثل حوالي 5.48 \% من عام 2005. وقد تبين من

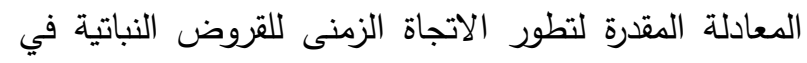

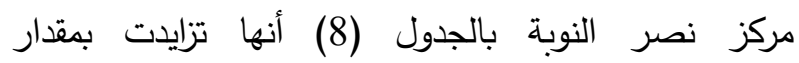
غيرمعنوى أحصائي بلغ حوالي 0.904 ألف جنية، بالنورل بمعدل زيادة سنوى بلغ حوالي 0.19 \% من متوسط القروض النباتية

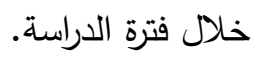


جدول 8. نتائج التقدير الاحصائي لمعادلات الاتجاة الزمنى للقروض النباتية في مراكز محافظة أسوان خلال الفترة (2005 -

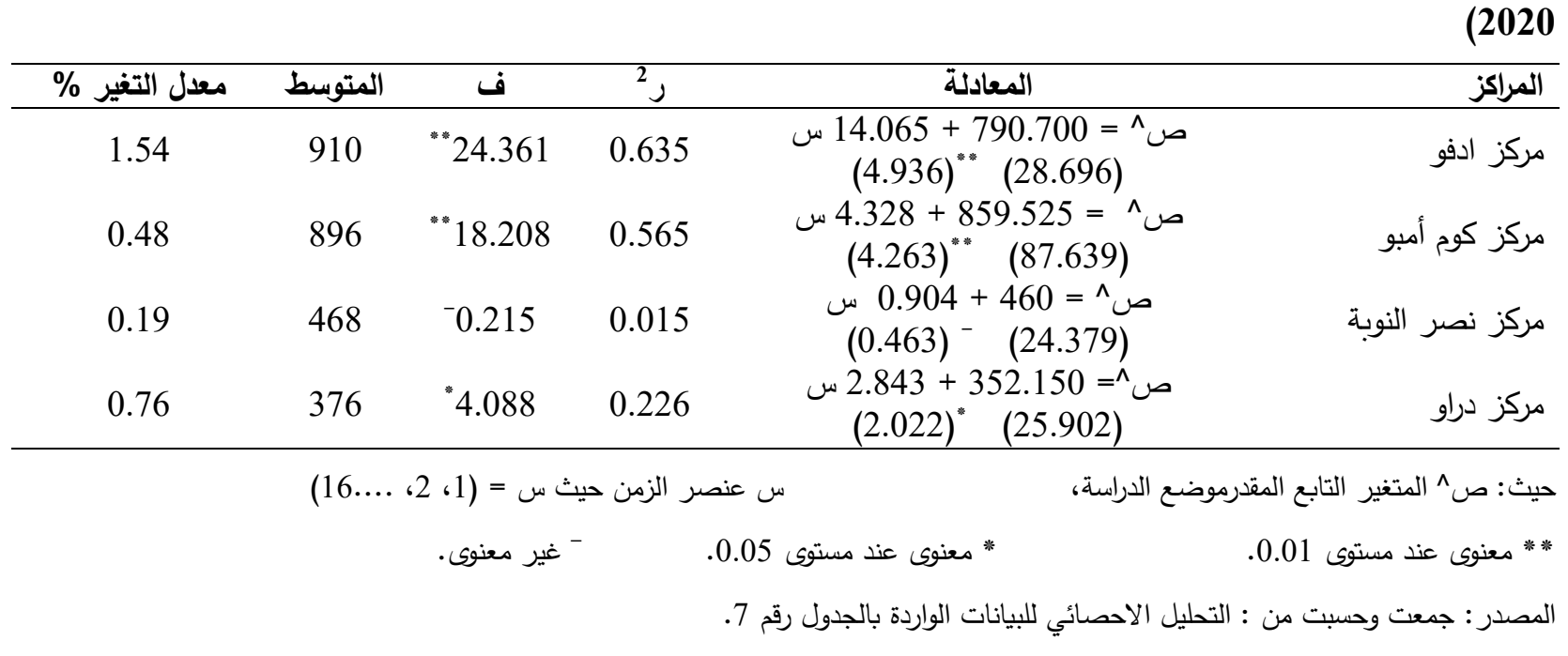

القرض وفوائدة وهذا ئؤدي إلى رفع نسبة السداد للقروض

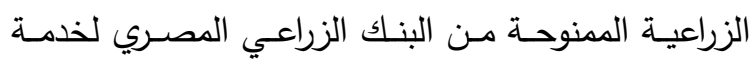

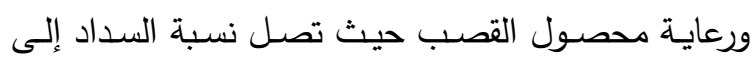
حوالي 99\%. 3- تمنح قروض محصول القصب لخدمة القصب الجديد

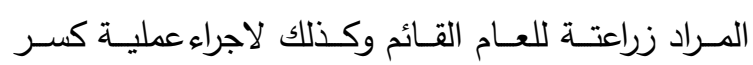
محصول القصب الحالي الموجود بالارض (الحصاد) ويتم

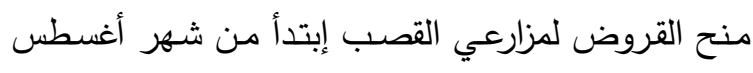

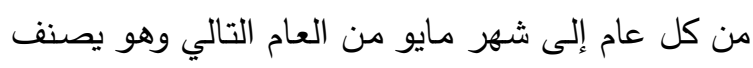

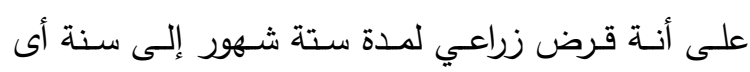
قروض قصيرة الأجل.

4- تمنح الفروض الزراعية لدحصول القصب بمعدل فائدة

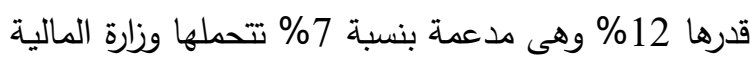
حيث يتم إعداد الكشـوف الخاصـة بـالمزارعين بأجمـالي قيمة الفوائد المستحقة بنسبة 7\% وترسل إلى وزارة المالية

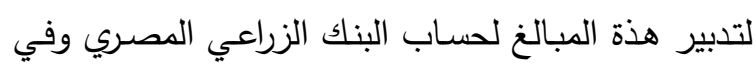

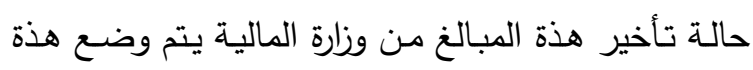

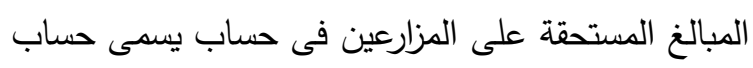

2- دراسة كفاءة الإيتمان الزرعي لأهم المحاصيل الزرعية فى محافظة أسوان:

أ- دراسة كفاءة الائتمان الزرعي لمحصول قصب السكر:

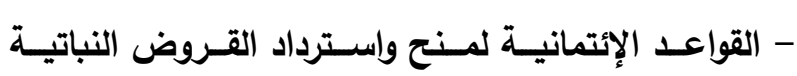
لمحصول القصب في محافظة أسوان: لكى يقوم البنك الزراعي المصري بمحافظة أسوان بأجراء

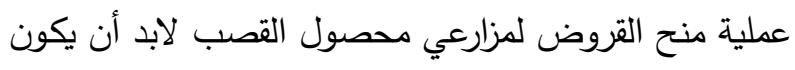

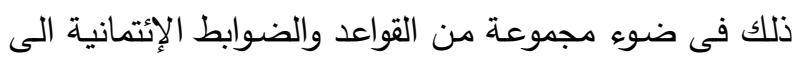

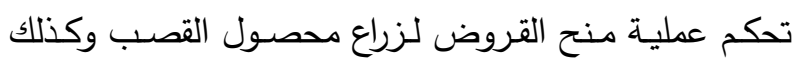
لضمان أسترداد هذة القروض من الزراع وهذة الضوابط هى:

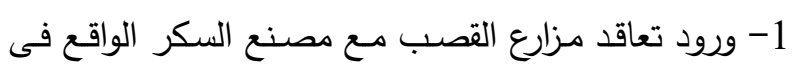

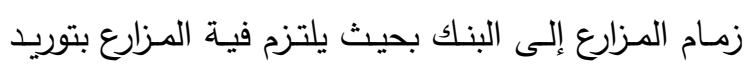
المحصول إلى المصنع.

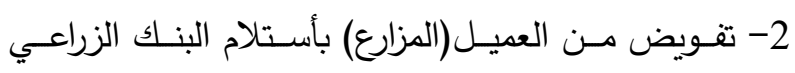
المصـري قيمة القرض كلة (القرض مضـافأ اليـة الفوائد

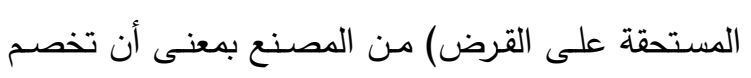

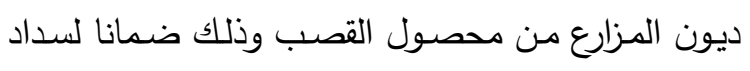


تطور التكاليف المتغيرة:

يتضح من البيانات الواردة بالجدول (9) أن متوسط

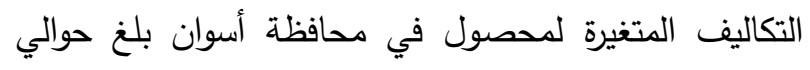

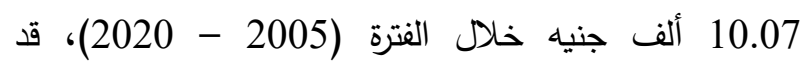

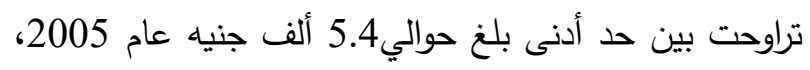
وحد أقصى بلغ حوالي 20.8 ألف جنيه عام 2020 2023، بزيادة

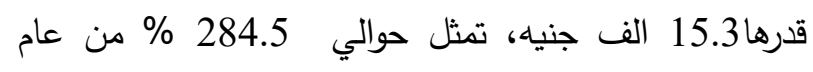
2005. وقد تبين من المعادلة المقدرة لتطور الاتجاة الزمنى تلفي للتكاليف المتغيرة لدحصول القصب في محافظة أسوان التبان بالجدول (10) أنها تزايدت بمقدار معنوى أحصائي بلغ حوالى لمالى

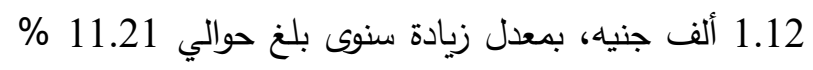
من متوسط التكاليف المتغيرة خلال فترة الدراسة. تطور التكاليف الكلية: تبين من البيانات الواردة بالجدول (9) أن متوسط لئلئ التكاليف الكلية لمحصول القصب في محافظة أسوان بلغ التيات التورن

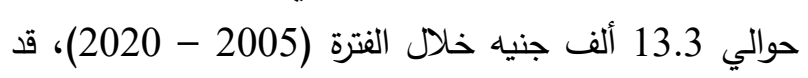
تراوحت بين حد أدنى بلغ حوالي 6.6 ألف جنيه عام 2005،

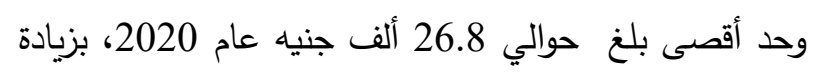

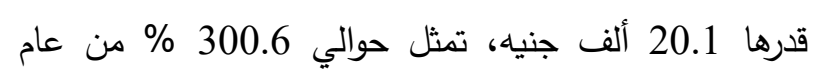

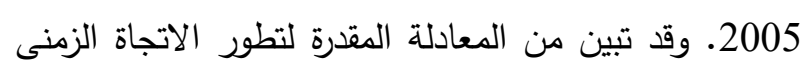

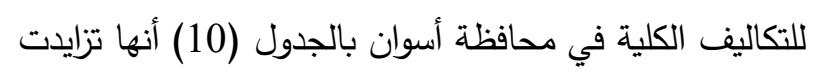
بمقدار معنوى أحصائي بلغ حوالي 1.47 ألف جنيه، بمعدل

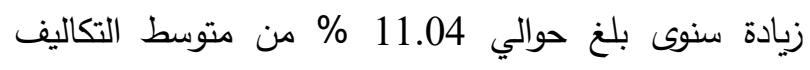
الكلية خلال فترة الدراسة. تطور قيمة القرض للفذان:

يتبين من البيانات الواردة بالجدول (9) أن متوسط قيمة القرض الممنوح للفدان لمحصول القصب في محافظة أسوان

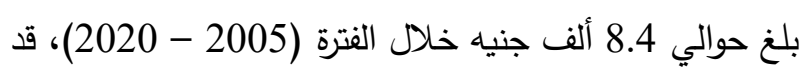
تراوحت بين حد أدنى بلغ حوالي 6 ألف جنيه عام 2005،

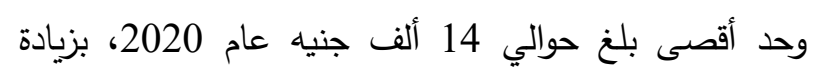
قدرها 8 ألف جنيه، تمثل حوالي 133.33 \% من عام
الدعم، ويتحمل المزارع معدل فائدة 5\% فقط من إجمالي معدل فائدة 12\%. 5- يتم عمل ميزان إئتمانى لكل عميل يوضح يوضح بة قيمة

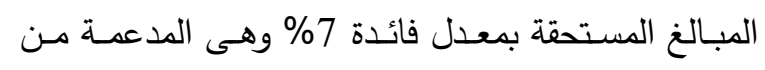
وزارة الماليـة وكذلك قيمـة الفائدة المستحقة عليـة بمعدل .\%5

6- فى حالة تأخير المزارع عن دفع المبالغ المستحقة علية

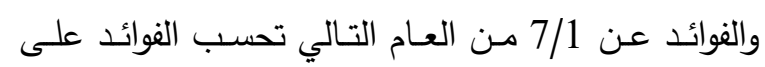

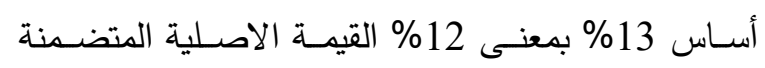

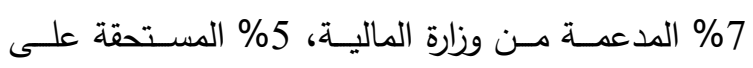
المزارع بالاضافة إلى 1\% غرامة وزامة أو عمولة تأخير ويطبق ذلك على المزارعين اللذين لم يقومو بزراعة القصب أصلا الصا

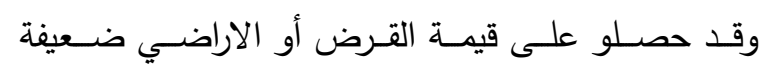

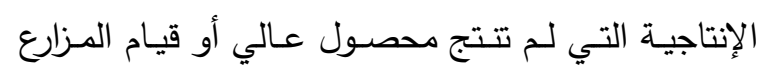

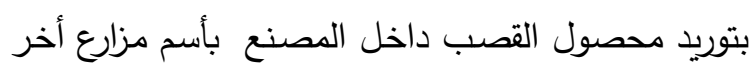

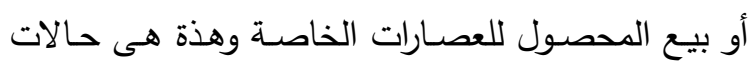

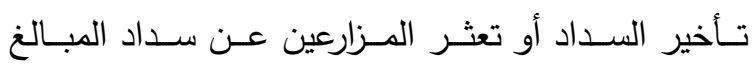

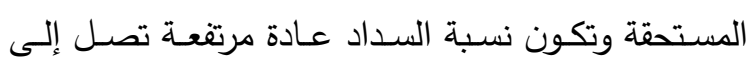
99 بسبب تعاقد المزارع مـع المصنع وتفويض العميل

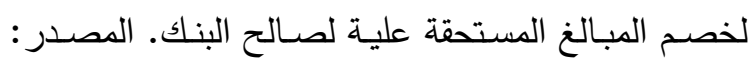

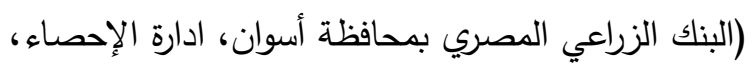

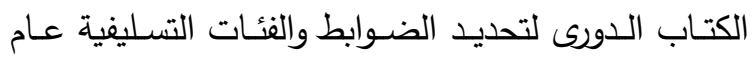
. (2020

- المؤشرات الاقتصادية للكفاءة الإتتمانية لمحصول القصب في محافظة أسوان:

يتاول هذا الجزء من البحث تطور التكاليف المتغيرة

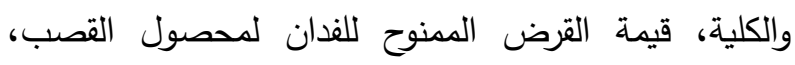
وحجم القروض المدنوحة ليحصول القصب وهى ممثلة بالقروض النباتية، ونسبة تغطية القروض الفدانية للتكاليف المتغيرة، وصافي العائد الفداني في محافظة أسوان خلال الفترة(2005-2020). 
تساوى قيمة القروض النباتية حيث أن 100\% من القروض

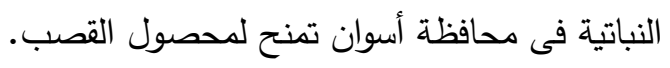
تطور نسبة تفطية القروض الفذانية للتكاليف المتفيرة: تبين من البيانات الواردة بالجدول (9) أن متوسط نسبة تغطية القروض الفدانية للتكاليف المتغيرة في محافظة أسوان بلغ حوالي 84 \% خلال الفترة (2005 - 2020)، قد الد تراوحت بين حد أدنى بلغ حوالي 55 \% عام عام 2008 عالف 2018، وحد

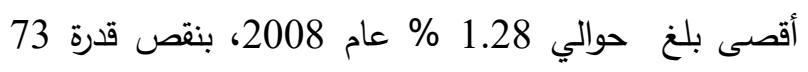

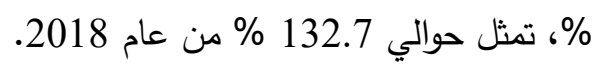

2005. وقد تبين من المعادلة المقدرة لتطور الاتجاة الزمنى

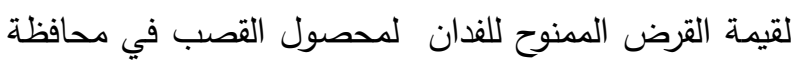
أسوان بالجدول (10) أنها تزايدت بمقدار معنوى أحصائي

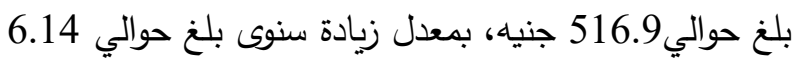
\% من متوسط قيمة القرض للفذان خلال فترة الدراسة. تطور حجم القروض الممنوحة للمحصول: بدراسة قيمة القروض الممنوحة لمحصول القصب في محافظة أسوان تبين من البيانات الواردة بالجدول (9) أنها جدول 9. المؤشرات الاقتصادية والإتتمانية للقروض الممنوحة لمصصول القصب في محافظة أسوان خلال الفترة (2005(2020

\begin{tabular}{|c|c|c|c|c|c|c|c|}
\hline صافي العائد & الإنتاليفة & نسبة التغطية" & 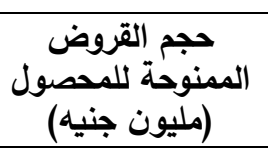 & قيمة القرض & التكاليفة & التكتغليفة & السنوات \\
\hline 990 & 300 & 1.11 & 2495 & 6000 & 6690 & 5410 & 2005 \\
\hline 1135 & 300 & 1.08 & 2530 & 6000 & 6855 & 5530 & 2006 \\
\hline 2327 & 300 & 1.20 & 2555 & 6000 & 6500 & 5010 & 2007 \\
\hline 4553 & 325 & 1.28 & 2578 & 6500 & 6585 & 5085 & 2008 \\
\hline 4500 & 325 & 1.25 & 2608 & 6500 & 6795 & 5195 & 2009 \\
\hline 4469 & 325 & 1.20 & 2671 & 6500 & 7584 & 5434 & 2010 \\
\hline 6612 & 350 & 1.33 & 2604 & 7000 & 7668 & 5278 & 2011 \\
\hline 7239 & 350 & 0.96 & 2541 & 7000 & 10047 & 7267 & 2012 \\
\hline 5058 & 375 & 0.86 & 2515 & 7500 & 12330 & 8750 & 2013 \\
\hline 5008 & 375 & 0.81 & 2611 & 7500 & 13352 & 9302 & 2014 \\
\hline 4720 & 450 & 0.88 & 2692 & 9000 & 15480 & 10210 & 2015 \\
\hline 4628 & 450 & 0.85 & 2693 & 9000 & 15572 & 10562 & 2016 \\
\hline 14288 & 550 & 0.72 & 2807 & 11000 & 19874 & 15374 & 2017 \\
\hline 11198 & 550 & 0.55 & 2829 & 11000 & 24802 & 20002 & 2018 \\
\hline 6937 & 700 & 0.67 & 2800 & 14000 & 26903 & 20903 & 2019 \\
\hline 8478 & 700 & 0.67 & 2880 & 14000 & 26802 & 20802 & 2020 \\
\hline \multirow[t]{4}{*}{5759} & 420 & 0.84 & 2651 & 8406 & 13365 & 10007 & المتوسط \\
\hline & & & & \multicolumn{4}{|c|}{ * تم حساب التكاليف الإثتمانية على أساس معدل الفائدة 5 \%\%. } \\
\hline & & & & \multicolumn{4}{|c|}{ "نسبة التغطية = قيمة القرض الممنوح للفدان / التكاليف المتغيرة. } \\
\hline & & & & \multicolumn{4}{|c|}{ "التكاليف الإنتمانية = قيمة القرض للفدان * معدل الفائدة. } \\
\hline
\end{tabular}


بلخ حوالى جنيه، 25.8 جنية بمعدل زيادة سنوى بلغ حوالي 6.15 \% من متوسط التكاليف الإتثمانية خلال فترة الدراسة. تطور صافي العائد الفداني: تبين من البيانات الواردة بالجدول(9) أن متوسط صافي

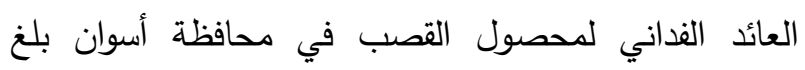

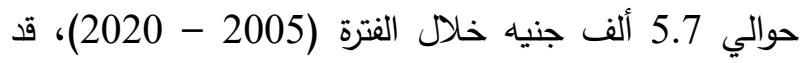

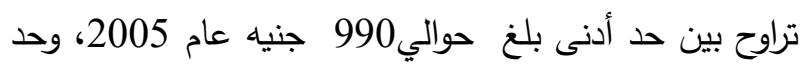
أقصى بلغ حوالي 14.2 ألف جنيه عام 2017، برانئ بنيادة قدرها 13.2 ألف جنيه، تمثل حوالي 1343.2 \% من عن عام 2005. وقد تبين من المعادلة المقدرة لتطور الاتجاة الزمنى لصافي

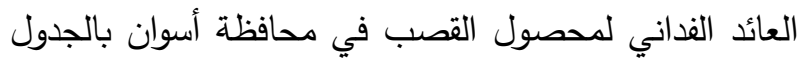

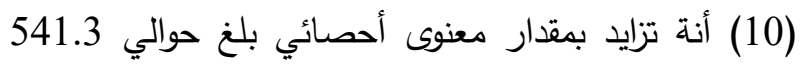
جنيه، بمعدل زيادة سنوى بلغ حوالي 9.39 \% من من متوسط دارئ صافي العائد الفداني خلال فترة الدراسة.
وقد تبين من المعادلة المقدرة لتطور الاتجاة الزمنى لنسبة تغطية القروض الفذانية للتكاليف المتغيرة بالجدول (10) أنها تتاقصت بمقدار معنوى أحصائي بلغ حوالي 0.044 ألف الف الفئ جنيه، بمعدل انخفاض سنوى بلغ حوالي 5.23 \% من متوسط نسبة تغطية القروض الفدانية للتكاليف المتغيرة خلال

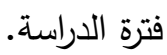
تطور التكاليف الإتتمانية: تبين من البيانات الواردة بالجدول (9) أن متوسط

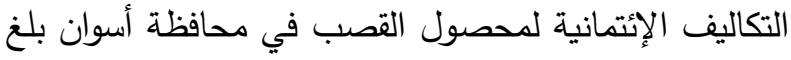
حوالي 420 جنيه خلال الفترة (2005 - 2020)، قد تراوحت بين حد أدنى بلغ حوالي 300 جنيه عام 2005، وحد أقصى بلغ حوالي 700 جنية عام 2020 بزيادة قدرها 400 جنيه، تمثل حوالي 133.3 \% من عام 2005. وقد تبين من المعادلة المقدرة لتطور الاتجاة الزمنى للتكاليف الإتتمانية بالجدول(10) أنها تزايدت بمقدار معنوى أحصائي

جدول 10. نتائج التقدير الإحصائي لمعادلات الاتجاة الزمنى للمؤشرات الاقتصادية والإتتمانية للقروض الممنوحة لمحصول القصب في محافظة أسوان خلال الفترة (2005-2020)

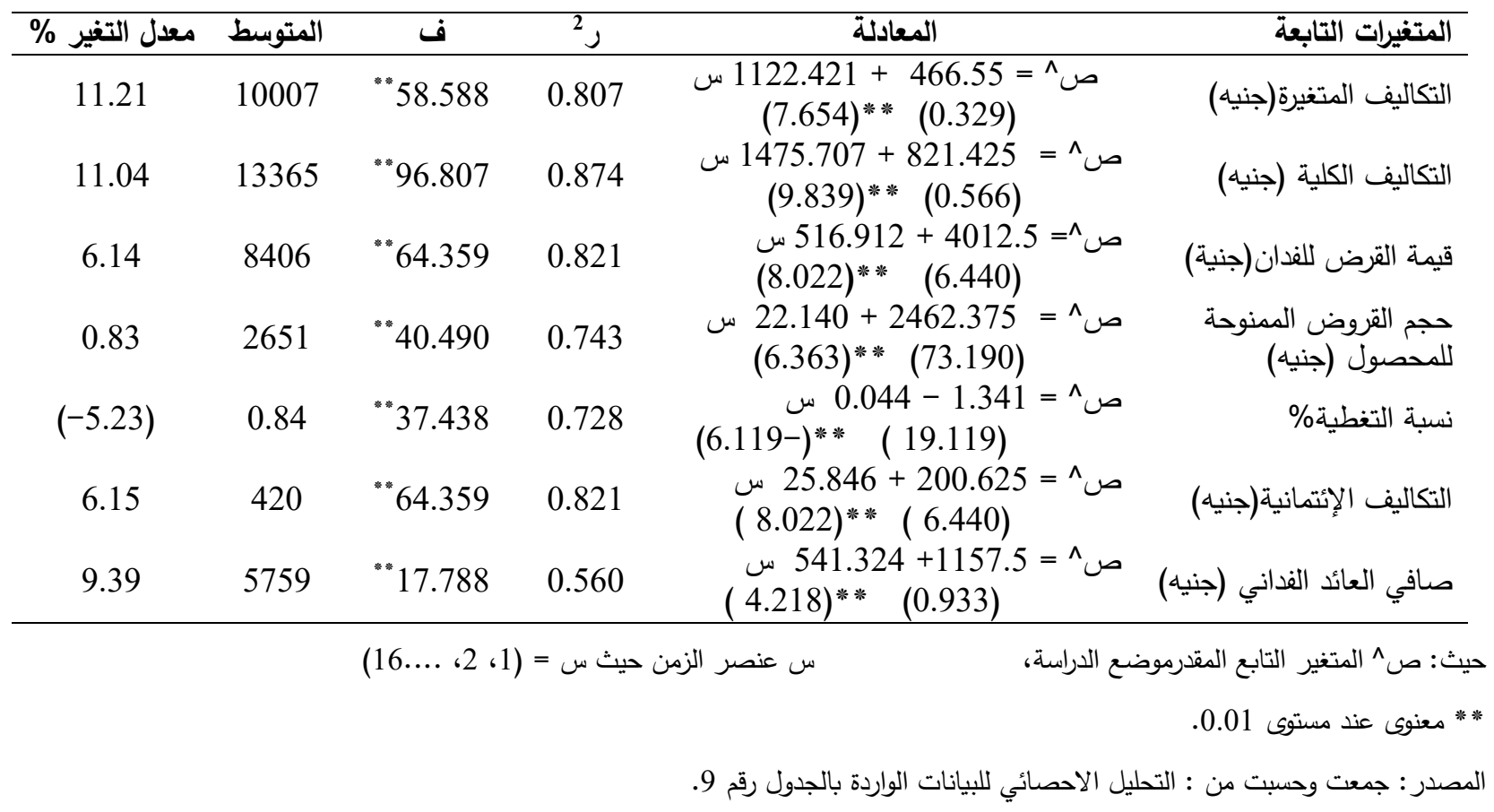


ب- دراسـة الـوض الـراهن للإئتمـان الزراعـي لمحصـول تطور التكاليف المتغيرة:

تبين من البيانات الواردة بالجدول(11) أن متوسط البطيف القمح في محافظة أسوان:

التكاليف المتغيرة لمحصول القدح في محافظة أسوان بلغ النغ الفيات

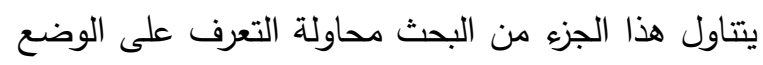

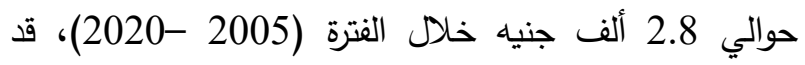

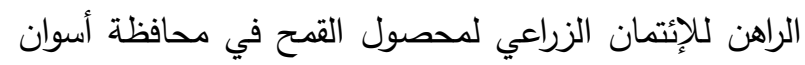
تراوحت بين حد أدنى بلغ حوالي 1.1 ألف جنيه عام 2005، حالف

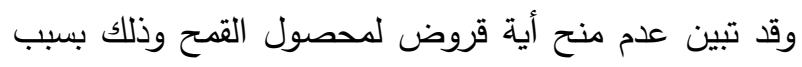

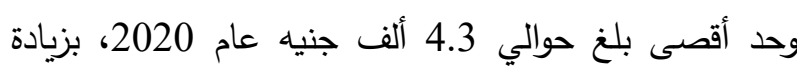

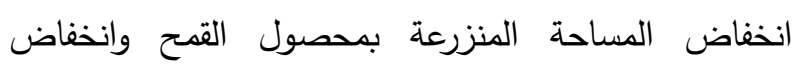
قدرها 3.1 ألف جنيه، تمثل حوالى 259.8 \% من من عام متوسط الإنتاجية الفدانية والتى تبلغ حوالى 13 أردب للفدان. 2005. وقد تبين من المعادلة المقدرة لتطور الاتجاة الزمنى تلى

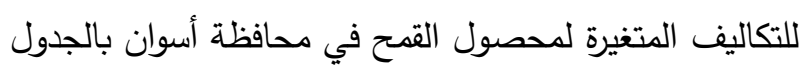

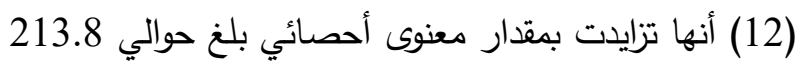
المصدر : (وزارة الزراعة واستصلاح الاراضي، مديرية الزراعة الفالية

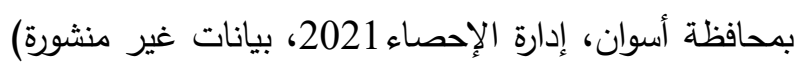
بسبب عدم ملائمة الظروف الجوية لإنتاجة فى محافظة الإحساء

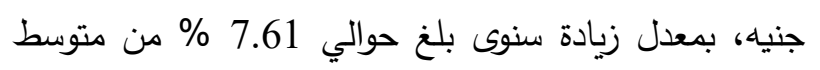
التكاليف المتغيرة خلال فترة الدراسة.

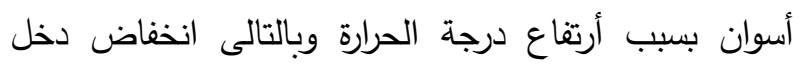
الزراع مما يؤدي إلى انخفاض نسبة السداد لذلك تتجة السياسة الإتثمانية الى تمويل محصول القصب وتوجية كل الفل

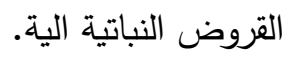

جدول 11. المؤشرات الاقتصادية لإنتاج محصول القمح في محافظة أسوان خلال الفترة(2005-2020)

\begin{tabular}{|c|c|c|c|}
\hline صافي العائد الفداني & التكاليف الكلية & التكاليف المتغيرة & السنوات \\
\hline 3455 & 2045 & 1195 & 2005 \\
\hline 3395 & 2205 & 1305 & 2006 \\
\hline 3447 & 2503 & 1503 & 2007 \\
\hline 3128 & 3120 & 1920 & 2008 \\
\hline 2596 & 3605 & 2105 & 2009 \\
\hline 2910 & 4050 & 2250 & 2010 \\
\hline 1070 & 4690 & 2490 & 2011 \\
\hline 1486 & 5060 & 2760 & 2012 \\
\hline 2020 & 5380 & 2980 & 2013 \\
\hline 2776 & 5600 & 3200 & 2014 \\
\hline 2000 & 6000 & 3500 & 2015 \\
\hline 2100 & 6150 & 3600 & 2016 \\
\hline 4125 & 6400 & 3750 & 2017 \\
\hline 6000 & 6600 & 3900 & 2018 \\
\hline 5740 & 7000 & 4150 & 2019 \\
\hline 5310 & 7300 & 4300 & 2020 \\
\hline 3222 & 4857 & 2807 & المتوسط \\
\hline
\end{tabular}

المصدر : جمعت وحسبت من بيانات : وزارة الزراعة واستصلاح الاراضي، مديرية الزراعة بمحافظة أسوان، إدارة الإحصاء، بيانات غير منثورة. 
الزمنى لصافي العائد الفداني لمحصول القصح في محافظة

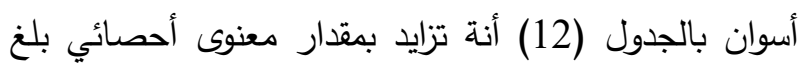

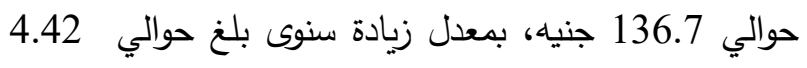
\% من متوسط صافي العائد الفداني خلال فترة الدراسة.

رابعا: دراسـة تطوروكفاءة قروض المشروعات الاستثمارية لإنتاج اللحوم الحمراء في محافظة أسوان

يتــاول هـا الجزء مـن البحث القواعد الإتثمانيـة لــنح

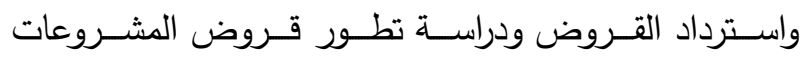
الاستثمارية لإنتاج اللحوم الحمراء في مراكز محافظة أسوان

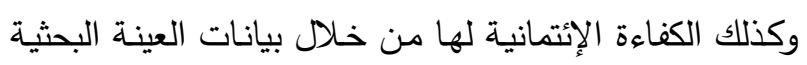
بمركزي أدفو وكوم أمبو.

1- دراسـة تطور قروض المشروعات الاستثمارية لإنتاج اللحوم الحمراء بمحافظة أسوان:

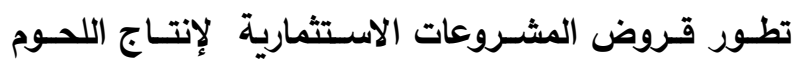
الحمراء بمركز ادفو: المروض

يتبين من البيانات الواردة بالجدول (13) أن متوسط قيمة

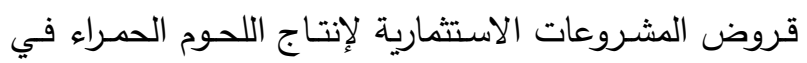

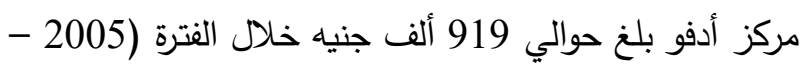
، (2020
تطور التكاليف الكلية: - ت يتضح من البيانات الواردة بالجدول(11) أن متوسط لكط لكئل التكاليف الكلية لمحصول القمح في محافظة أسوان بلغ البن

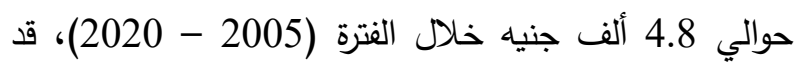
تراوحت بين حد أدنى بلغ حوالي 2 ألف جنيه عام 2005، وحد أقصى بلغ حوالي 7.3 ألف جنيه عام 2020 2020، بزيادة قدرها 5.2 ألف جنيه، تمثل حوالي 256.96 \% من من عن عام 2005. وقد تبين من المعادلة المقدرة لتطور الاتجاة الزمنى

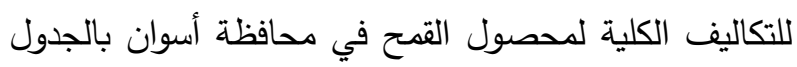
(12) أنها تزايدت بمقدار معنوى أحصائي بلغ حوالي 362.2

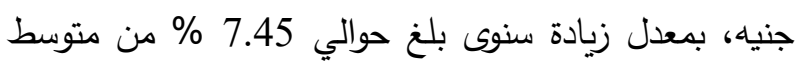
القروض النباتية خلال فترة الدراسة. تطور صافي العائد الفداني: تبين من البيانات الواردة بالجدول(11) أن متوسط صافي

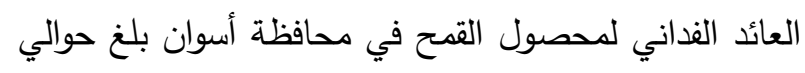
3.2 ألف جنيه خلال الفترة (2005 - 2020)، قد تراوحت بين حد أدنى بلغ حوالي 1 ألف جنية عام 2011، 2012، وحد أقصى بلغ حوالي 5.7 ألف جنيه عام 2019، بلفي بزيادة قدرها

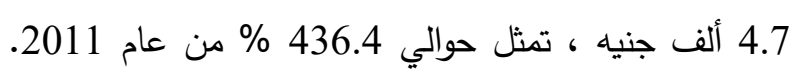
وقد تبين من المعادلة المقدرة لتطور الاتجاة

جدول 12. نتائج التقدير الاحصائي لمعادلات الاتجاة الزمنى للمؤشرات الاقتصادية لإنتاج محصول القمح في محافظة أسوان خلال الفترة (2005-2020).

\begin{tabular}{|c|c|c|c|c|c|}
\hline معدل التغير\% & المتوسط & ف & ${ }^{2} \mathrm{~s}$ & المعادلة & المتغيرات الاقتصادية \\
\hline 7.61 & 2807 & "2192.95 & 0.994 & 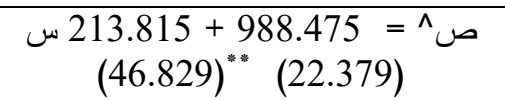 & التكاليف المتغيرة (جنيه) \\
\hline 7.45 & 4857 & "663.164 & 0.979 & ص ص = & التكاليف الكلية(جنيه) \\
\hline 4.24 & 3222 & 3.485 & 0.199 & ص^ = & صافي العائد الفداني(جنيه) \\
\hline
\end{tabular}

س عنصر الزمن حيث س = (1)، 2، . 16... حيث: ص^ الدتغير التابع المقدرموضع الدراسة،

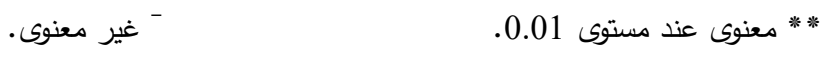
المصدر : جمعت وحسبت من: التحليل الاحصائي للبيانات الواردة بالجدول 11. 


\begin{tabular}{|c|c|c|c|c|c|}
\hline \multirow{2}{*}{ إجمالى القروض النباتية } & \multicolumn{4}{|c|}{ المراكز } & \multirow[b]{2}{*}{ السنوات } \\
\hline & (ألف جنيه) & (ألف جنية النوبة) & (ألف جنيه) & (ألف جنيه) & \\
\hline 2399 & 241 & 308 & 955 & 895 & 2005 \\
\hline 2415 & 246 & 319 & 951 & 899 & 2006 \\
\hline 2431 & 254 & 322 & 953 & 902 & 2007 \\
\hline 2467 & 270 & 337 & 956 & 904 & 2008 \\
\hline 2434 & 246 & 298 & 999 & 891 & 2009 \\
\hline 2398 & 216 & 278 & 1015 & 889 & 2010 \\
\hline 2479 & 223 & 284 & 1032 & 940 & 2011 \\
\hline 2474 & 221 & 277 & 1058 & 918 & 2012 \\
\hline 2499 & 225 & 255 & 1078 & 941 & 2013 \\
\hline 2542 & 245 & 273 & 1095 & 929 & 2014 \\
\hline 2558 & 256 & 329 & 1053 & 920 & 2015 \\
\hline 2556 & 282 & 432 & 925 & 917 & 2016 \\
\hline 2556 & 273 & 335 & 1028 & 920 & 2017 \\
\hline 2674 & 261 & 296 & 1217 & 900 & 2018 \\
\hline 2472 & 240 & 268 & 997 & 967 & 2019 \\
\hline 2495 & 245 & 272 & 1009 & 969 & 2020 \\
\hline 2491 & 247 & 305 & 1020 & 919 & المتوسط \\
\hline
\end{tabular}

المصدر : جمعت وحسبت من بيانات: البنك الزراعي المصري بمحافظة أسوان، إدارة الإحصاء، بيانات غير منشورة.

مركز كوم أمبو بلغ حوالي 1.02 مليون جنيه خـال الفترة

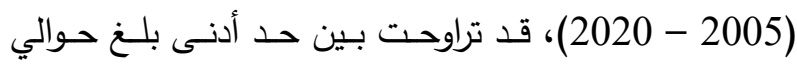

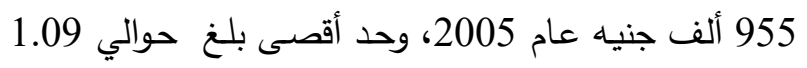

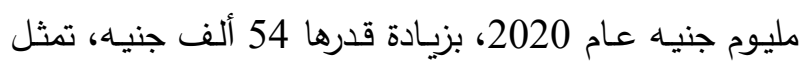

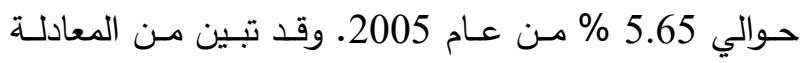

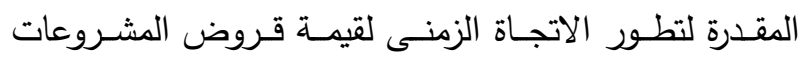

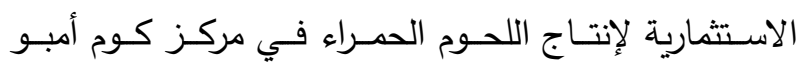
بالجدول (14) أنها تزايدت بمقدار غير معنوى أحصائي بلغ الحئ

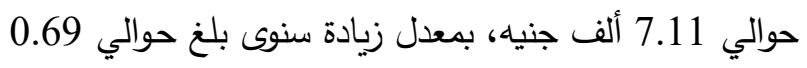
\% مـن متوســـــروض المشـروعات الاسـتثارية لإنتـاج

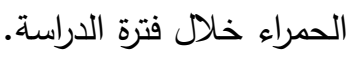

قد تراوحت بين حد أدنى بلـخ حوالي 895 ألف جنيه عام

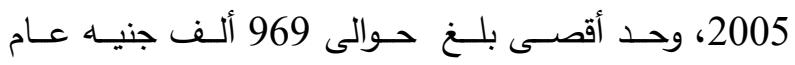
2020، بزيادة قدرها 74 ألف جنية، تمثل حوالي 8.26 \% من عام 2005. وقد تبين من المعادلة المقدرة لتطور الاتجاة

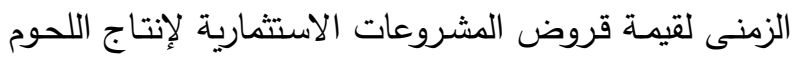
الحمراء في مركز أدفو بالجدول (14) أنها تزايدت بمقدار

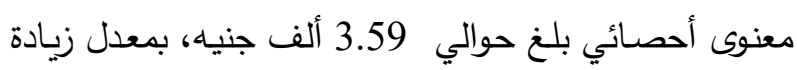
سنوى بلغ حوالي 0.39 \% من متوسط قروض المشروعات الاستثمارية للإنتاج الحمراء خلال فترة الدراسة.

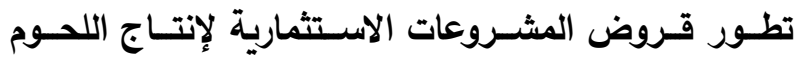

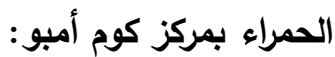

يتبين من البيانات الواردة بالجدول (13) أن متوسط قيمة قروض الششروعات الاستثمارية لإنتاج اللحوم الحمراء في لإني 

عبد العاطي محمد محمود علي: دراسة إقتصادية لدور البنك الزراعي المصري في تمويل الأنشطة الزراعية ...

جدول 14. نتائج التقدير الاحصائي لمعادلات الاتجاة الزمنى لقروض المشروعات الاستثمارية لإنتاج اللحوم الحمراء في محافظة أسوان خلال الفترة(2005-2020).

\begin{tabular}{|c|c|c|c|c|c|}
\hline معدل التغير\% & المتوسط & ف & $2 ر$ & المعادلة & المراكز \\
\hline 0.39 & 919 & " 12.332 & 0.468 & ص ص = = $3.593+888.27$ س & مركز ادفو \\
\hline 0.69 & 1020 & -3.954 & 0.220 & ص 1 = & مركز كوم أمبو \\
\hline$(-0.18)$ & 305 & 0.052 & 0.004 & ص ص^ = & مركز نصر النوبة \\
\hline 0.36 & 247 & 0.722 & 0.049 & $\begin{array}{c}0.894+238.9=\wedge \text { ص } 0.94)^{-}(23.476) \\
(0.850)^{-}\end{array}$ & مركز دراو \\
\hline
\end{tabular}
عنصر الزمن حيث س = (1، 2، ....16).

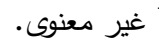

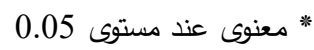
حيث: ص^ المتغير التابع المقدموضع الدراسة، المصدر : جمعت وحسبت من: التحليل الاحصائي للبيانات الواردة بالجدول 13.

في مركز دراو بلغ حوالي 247 ألف جنيه خلال الفترة (2005 - 2020)، قد تراوحت بين حد أدنى بلغ حوالي 241 ألف جنيه عام 2005، وحد أقصى بلغ حوالي 245 جنيه عام 2020، بزيادة قدرها 4 ألف جنيه، تمثل حوالي 1.65 \% من عام 2005. وقد تبين من المعادلة المقدرة لتطور الاتجاة الزمنى لقيمة قروض المشروعات الاستثمارية لإنتاج اللحوم الحمراء في مركز دراو بالجدول (14) أنها تزايدت بمقدار غيرمعنوى أحصائي بلغ حوالى 0.894 ألف دركز

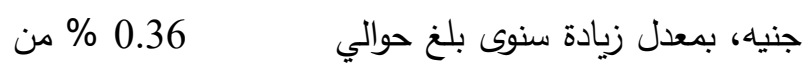
متوسط قروض المشروعات الاستثمارية لإنتاج الحمراء

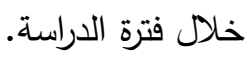

- القواعد الإئتمانيـة لمـنح واسـترداد قروض المشـروعات الاستثمارية لإنتاج اللحوم الحمراء في محافظة أسوان: لكى يقوم البنك الزراعي المصري بمحافظة أسوان بأجراء

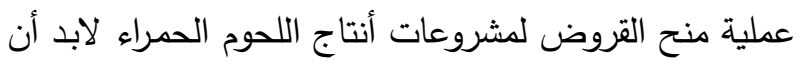
يكون ذلك فى ضوء مجموعة من القواعد والضوابط الإئمانية

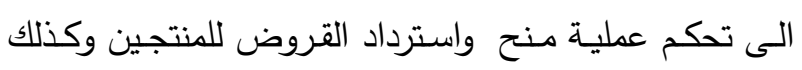
لضمان أستراد هذة القروض من الزراع وهذة الضوابط هى:
تطور قروض المشروعات الاستثمارية لإنتاج الحوم الحمراء بمركز نصر النوبة:

يتبين من البيانات الواردة بالجدول (13) أن متوسط قيمة قروض المشروعات الاستثمارية لإنتاج اللحوم الحمراء في مركز نصر النوبة بلغ حوالي 305 ألف جنيه خلال الفترة (2005 - 2020)، قد تراوحت بين حد أدنى بلغ حوالي 272 ألف جنيه عام 2020، وحد أقصى بلغ حوالي 432 ألف جنيه عام 2016، بنقص قدرة 160 ألف جنيه، تمثل حوالي 58.82 \% من عام 2016. وقد تبين من المعادلة المقدرة لتطور الاتجاة الزمنى لقيمة قروض المشروعات الاستثمارية لإنتاج اللحوم الحمراء في مركز نصر النوبة بالجدول (14) أنها تتاقصت بمقدار غير معنوى أحصائي بلغ حوالي 0.543 ألف جنيه، بمعدل انخفاض سنوى بلغ حوالي 0.18\% من قروض المشروعات الاستثمارية لإنتاج الحمراء متوسط خلال فترة الدراسة.

تطور قروض المشروعات الاستثمارية لإنتاج الحوم

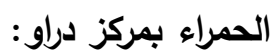

واتضح من البيانات الواردة بالجدول (13) أن متوسط قيمة قروض المشروعات الاستثارية لإنتاج اللحوم الحمراء 
يتبين من بيانات الجدول(15) بدراسة المؤشرات الاقتصادية والإيتمانية لقيمة القروض المهنوحة للمشروعات الاستثمارية لإنتاج اللحوم الحمراء خلال دورة الانتاج لتسمين عجول الفريزيان، الخليط، البلدى أن إجمالي التكاليف المتغيرة

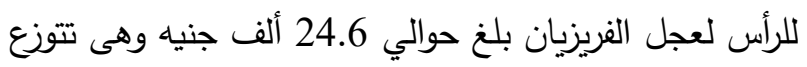
على عدة عناصر هى سعر الرأس، تكاليف الاعلاف المركزة، تكاليف الاعلاف الجافة، تكاليف الاعلاف الخضراء، تكاليف الخدمات البيطرية، تكايف العمالة وقد بلغ

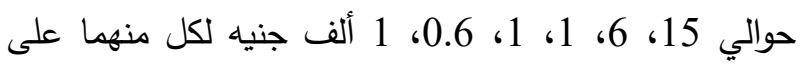
الترتيب تمثل حوالي 15 60.98، 24.4، 4.06 \% لكل منها على الترتيب وبلغت التكاليف الثابتة حوالي 467 جنيه موزعة على كل من قسط أهلاك المبنى

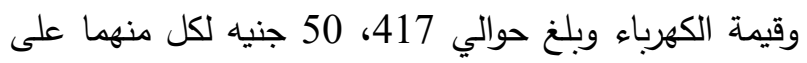

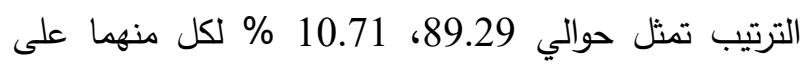
الترتيب وبلغت التكاليف الكلية حوالي 25.06 ألف جنيه،

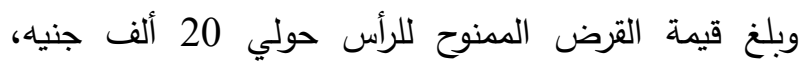
وبلغت نسبة تغطية القرض الممنوح للرأس إلى التكاليف المتغيرة حوالي 81\%، وبلغت التكاليف الإتتمانية بمعدل الفائدة 13\% بالاضافة إلى 1.5\% مصروفات ادارية حوالي الإلي 2.9 ألف جنيه، بينما بلغ إجمالي الايراد حوالي 36.3 ألف الف الف الفالي جنيه موزع على ايراد السماد وقيمة بيع الرأس وبلغ حوالي 1.5، 34.8 ألف جنيه لكل منها على الترتيب تمثل حوالي التران 4.13، 95.87 لكل منها على الترتيب، بلغ صافي العائد حوالى 11.2 ألف جنيه. فى حين بلغت التكاليف المتغيرة للابقار الخليط حوالي 19.8 ألف جنيه وهى تتوزع على عدة عناصر هى سعر الرأس، تكاليف الاعلاف المركزة، تكاليف الاعلاف الجافة، تكاليف الاعلاف الخضراء، تكاليف الخدمات البيطرية،
1- لابد من وجود شهادة الحيازة الزراعية كثرط أساسي لكنح القروض للأفراد وهى تعتبر من أهم الضمانات لأسترداد القروض.

2- يتم هنح القروض بحد أقصي ثلاث رؤؤس تسمين للفدان. 3- تمنح قروض المشروعات الاستثمارية لإنتاج اللحوم

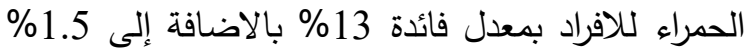
مصروفات إدارية تخصم عند منح القرض من قيمة

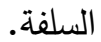

4- تعتبر قروض المشروعات الاستمارية قروض قصيرة الاجل تمنح لمدة سنة واحدة.

5- قيمة القرض المنوح لتسمين عجول الفريزيان يبلغ حوالي 20 ألف جنيه تبلغ قيمة قرض شراء الرأس 15 ألف جنيه، 5 ألاف جنيه قيمة قرض تغذية الرأس، قيمة القرض الممنوح لتسمين عجول الخليط 15 ألف جنيه تبلغ النغ الترانيه قيمة قرض شراء الرأس 10 ألاف جنيه، 5 ألاف جنيه قيمة قرض تغذية الرأس، قيمة القرض الممنوح لتسمين عجول البلدى 15 ألف جنيه تبلغ قيمة قرض شراء الرأس الرض 10 ألاف جنيه، 5 ألاف جنيه قيمة قرض تغذية الرأس. 6- يتم أسترداد القروض بأن يدفع المقترض في نهاية السنة الاولي قيمة القرض بالكامل بالآضافة إلى معدل فائدة

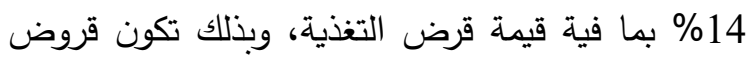
قصيرة الاجل لمدة سنة. المصدر: (البنك الزراعي

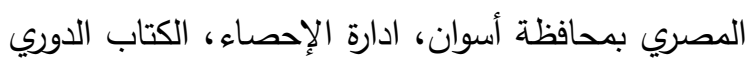

$$
\text { لتحديد الضوابط والفئات التسليفية عام 2020). }
$$

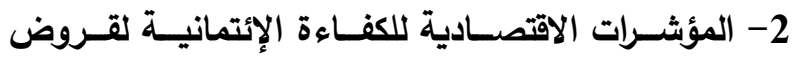

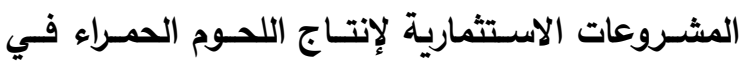

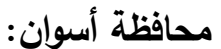



عبد العاطي محمد محمود علي: دراسة إقتصادية لدور البنك الزراعي المصري في تمويل الأنشطة الزراعية ...

جدول 15. المؤشرات الاقتصادية والإئتمانية لقيمة القروض الممنوحة لأنواع ماشية التسمين للمشروعات الاستثمارية لإنتاج (اللحوم الحمراء في محافظة أسوان (2020-2021)

\begin{tabular}{|c|c|c|c|c|c|c|c|c|}
\hline صافي العائد & ألإيرادي & الإئتمانية" التكاليف & التغطية " التسبة & للمشم القروضة & للرأسرض & التكاليفة & التكاليف & نوعاشية \\
\hline 11233 & 36300 & 2900 & 0.81 & \multirow{3}{*}{2.49} & 20000 & 25067 & 24600 & الفريزيان \\
\hline 9633 & 29900 & 2175 & 0.75 & & 15000 & 20267 & 19800 & الخليط \\
\hline 6733 & 23700 & 2175 & 0.90 & & 15000 & 16967 & 16500 & البلدى \\
\hline
\end{tabular}

* تم إضافة 1.5 \% من إجمالي قيمة القرض مصروفات ادارية إلى قيمة التكاليف الإتتمانية.

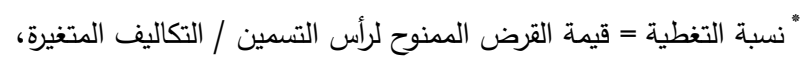
"التكاليف الإتتمانية = قيمة القرض لرأس التسمين * معدل الفائدة. "صافي العائد = إجمالي الايراد - التكاليف الكلية. المصدر : جمعت وحسبت من بيانات: 1- البنك الزراعي المصري بمحافظة أسوان، ادارة الإحصاء، الكتاب الاحصائي الدورى لتحديد الضوابط والفئات التسليفية عام 2020).

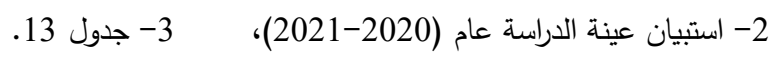

فى حين بلغت التكاليف المتغيرة للابقار البلدى حوالي 16.5 ألف جنيه وهى تتوزع على عدة عناصر هي سعر لئى الرأس، تكاليف الاعلاف المركزة، تكاليف الاعلاف الجافة، تكاليف الاعلاف الخضراء، تكاليف الخدمات البيطرية، تكاليف العمالة وقد بلغ حوالي 10، 4.5، 0.7، 0.5، 0.3، 0.5 ألف جنيه لكل منهما على الترتيب تمثل حوالي 601 كوالي 60.61 منها على الترتيب وبلغت التكاليف الثابتة حوالي 467 جنيه موزعة على كل من قسط أهلاك المبنى وقيمة الكهرباء وبلغ حوالي 417، 50 جنيه لكل منهما على الترتيب تمثل حوالي 89.29، 10.71 \% لكل منهما على الترتيب وبلغت التكاليف الكلية حوالي 16.96 ألف جنيه، وبلغ قيمة القرض الممنوح للرأس حولي 15 ألف جنيه، وبلغت نسبة تغطية القرض جوليه الممنوح للرأس إلى التكاليف المتغيرة حوالي 90\% جوبن، وبلغت

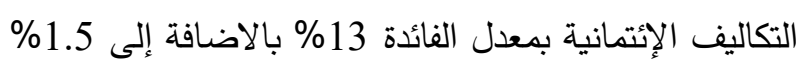

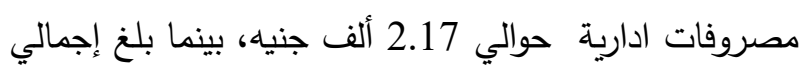
الايراد حوالي 23.7 ألف جنيه موزع على ايراد السماد وقيمة
تكاليف العمالة وقد بلغ حوالي 12، 5.2، 0.85، 0.7، 0.45، 0.6 ألف جنيه لكل منهما على الترتيب تمثل حوالي 60.61، 26.26، 4.29، 3.53، 2.27، 3.04 \% لكل منها على الترتيب وبلغت التكاليف الثابتة حوالي 467 جنية موزعة على كل من قسط أهلاك المبنى وقيمة الكهرباء وبلغ حنغ حوالي 417، 50 جنيه لكل منهما على الترتيب تمثل حوالي 89.29، 10.71 \% لكل منهما على الترتيب وبلغت التكاليف الكلية حوالي 20.26 ألف جنيه، وبلغ قيمة القرض ملإل الممنوح للرأس حولى 15 ألف جنيه، وبلغت نسبة تغطية القرض الممنوح للرأس إلى التكاليف المتغيرة حوالي 75\% وبلغت التكاليف الإئتمانية بمعدل الفائدة 13\% بالاضافة إلى إلى

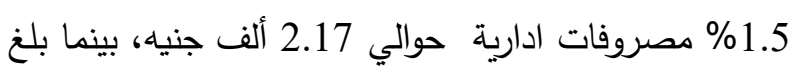
إجمالي الايراد حوالي 29.9 ألف جنيه موزع على ايراد السماد وقيمة بيع الرأس وبلغ حوالي 1.1، 28.8 ألف جنيه لكل منها على الترتيب تمثل حوالي 3.68، 96.32 ، لكل منها على الترتيب، بلغ صافي العائد حوالي 9.63 ألف جنيه. 
تطور قروض المشروعات الاستثمارية لإنتاج الألبان في

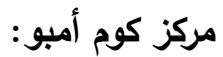

يتبين من البيانات الواردة بالجدول (16) أن متوسط قيمة قروض المشروعات الاستثمارية لإنتاج الألبان فى مركز كوم الإن الئات أمبو بلغ حوالي 143 ألف جنيه خلال الفترة (2005 2020)، قد تراوحت بين حد أدنى بلغ حوالي 47 ألف جنية الفية الفئ

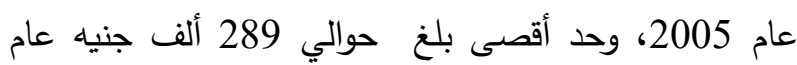

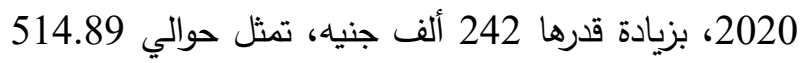
\% من عام 2005. وقد تبين من المعادلة المقدرة لتطور الاتجاة الزمنى لقيمة قروض المشروعات الاستثمارية لإنتاج

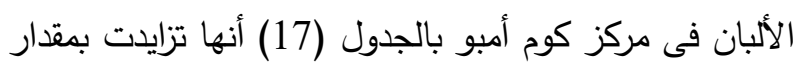

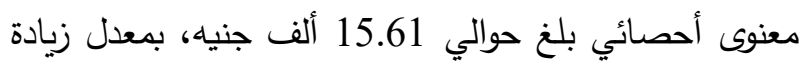

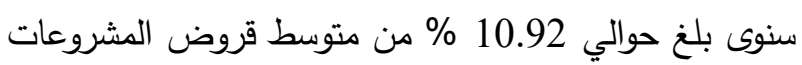
الاستثمارية لإنتاج الألبان خلال فترة الدراسة. تطور قروض المشروعات الاستثمارية لإنتاج الألبان بمركز

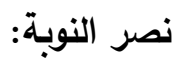
يتبين من البيانات الواردة بالجدول(16) أن متوسط قيمة

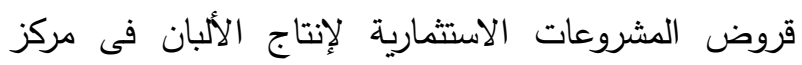
نصر النوبة بلغ حوالي 46 ألف جنيه خلال الفترة (2005 2020)، قد تراوحت بين حد أدنى بلغ حوالي 12 ألف جنيه

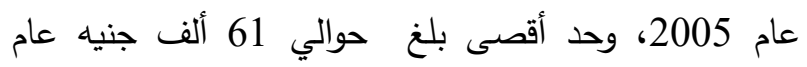
2020، بزيادة قدرها 49 ألف جنيه، تمثل حوالي 4005.33 \% من عام 2005. وقدادة تصاه تبين من المعادلة المقدرة لتطور الاتجاة الزمنى لقيمة قروض المشروعات الاستثمارية لإنتاج الألبان فى مركز نصرالنوبة بالجدول (17) أنها تزايدت بمقدار معنوى أحصائي بلغ حوالي 3.75 ألف جنيه، بمعدل زيادة سنوى بلغ حوالي 8.16 \% من متوسط قروض المشروعات الاستثمارية لإنتاج الألبان خلال فترة الدراسة.
بيع الرأس وبلغ حوالي 0.9، 22.8 ألف جنيه لكل منها على الترتيب تمثل حوالي 3.79، 96.21 لكل منها على الترتيب، بلغ صافي العائد حوالي 6.73 ألف جنيه. خامسا: دراسة تطوروكفاءة قروض المشروعات الاستثمارية لإنتاج الألبان في محافظة أسوان

يتناول هذا الجزء من البحث دراسة تطور قروض المشروعات الاستثمارية لإنتاج الألبان في مراكز محافظة أسوان وكنلك الكفاءة الإئيتمانية لها من خلال بيانات العينة البحثية بمركزي أدفو وكوم أمبو. 1- دراسة تطور قروض المشروعات الاستثمارية لإنتاج الألبان في محافظة أسوان:

تطور قروض المشروعات الاستثمارية لإنتاج الألبان بمركز ادفو:

يتضح من البيانات الواردة بالجدول(16) أن متوسط قيمة

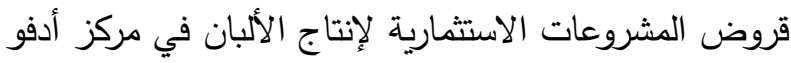

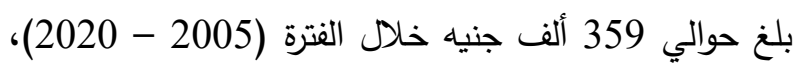
قد تراوحت بين حد أدنى بلغ حوالي 215 ألف جنيه عام

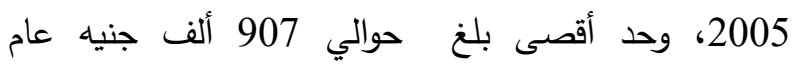
2020، بزيادة قدرها 692 ألف جنيه، تمثل حوالي 321.86 \% من عام 2005. وقد تبين من المعادلة الدقدرة لتطور الاتجاة الزمنى لقيمة قروض المشروعات الاستثمارية لإنتاج

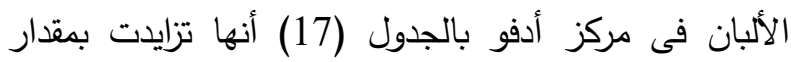
معنوى أحصائي بلغ حوالي 31.34 ألف جنيه، بمعدل زيادة سنوى بلغ حوالي 8.73 \% من متوسط قروض المشروعات الاستثمارية لإنتاج الألبان خلال فترة الدراسة. 
جدول 16. تطور قروض المشروعات الاستثمارية لإنتاج الألبان في محافظة أسوان خلال الفترة (2005-2020)

\begin{tabular}{|c|c|c|c|c|c|}
\hline \multirow{2}{*}{ إجمالي القروض النباتية } & \multicolumn{4}{|c|}{ المراكز } & \multirow[b]{2}{*}{ السنوات } \\
\hline & (ألف جنية) & نصر النوبة & (ألف جنية) أمبو) & (ألف جنية) & \\
\hline 295 & 21 & 12 & 47 & 215 & 2005 \\
\hline 300 & 21 & 14 & 45 & 220 & 2006 \\
\hline 301 & 16 & 16 & 43 & 226 & 2007 \\
\hline 309 & 33 & 26 & 65 & 185 & 2008 \\
\hline 405 & 36 & 31 & 71 & 267 & 2009 \\
\hline 449 & 43 & 39 & 82 & 285 & 2010 \\
\hline 429 & 33 & 38 & 72 & 286 & 2011 \\
\hline 552 & 37 & 46 & 163 & 306 & 2012 \\
\hline 614 & 50 & 53 & 175 & 336 & 2013 \\
\hline 685 & 52 & 62 & 193 & 378 & 2014 \\
\hline 768 & 75 & 75 & 233 & 385 & 2015 \\
\hline 947 & 80 & 135 & 322 & 410 & 2016 \\
\hline 363 & 90 & 36 & 74 & 163 & 2017 \\
\hline 535 & 79 & 35 & 125 & 296 & 2018 \\
\hline 1308 & 90 & 55 & 285 & 878 & 2019 \\
\hline 1350 & 93 & 61 & 289 & 907 & 2020 \\
\hline 601 & 53 & 46 & 143 & 359 & المتوسط \\
\hline
\end{tabular}

المصدر : جمعت وحسبت من بيانات : البنك الزراعي المصري بمحافظة أسوان، إدارة الإحصاء، بيانات غير منشورة.

جدول 17. نتائج التقدير الاحصائى لمعادلات الاتجاة الزمنى للقروض الاستثمارية المشروعات الاستثمارية لإنتاج الألبان في محافظة أسوان خلال الفترة (2005-2020)

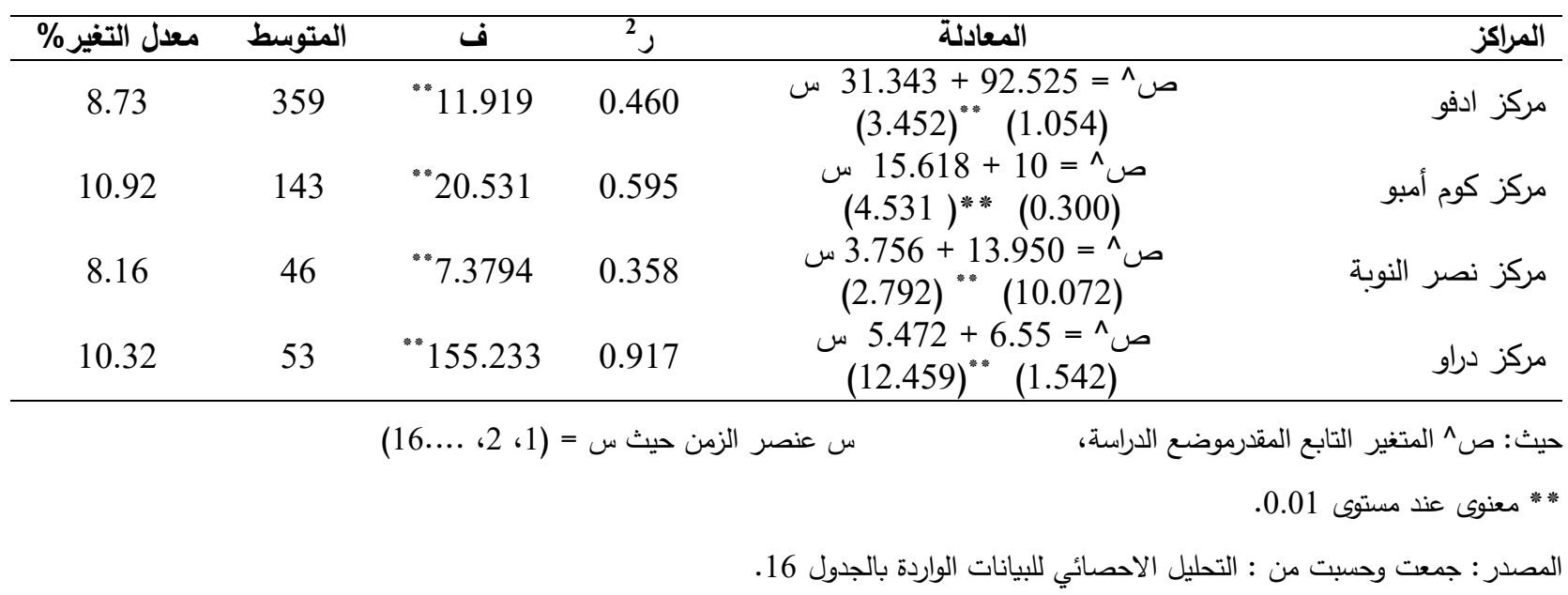

بلغ حوالي 53 ألف جنيه خلال الفترة (2005 - 2020)، قد

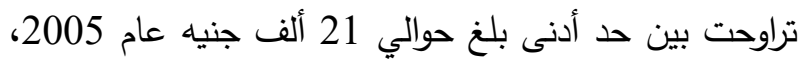

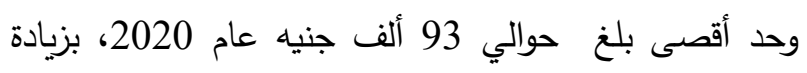
قدرها 72 ألف جنية، تمثل حوالي 342.85 \% من عام
تطور قروض المشروعات الاستثمارية لإنتاج الألبان

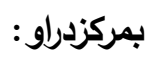

تبين من البيانات الواردة بالجدول (16) أن متوسط قيمة

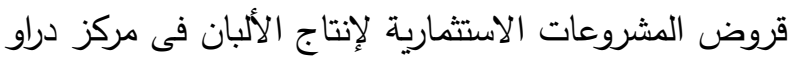


جنيه تبلغ قيهـة قرض شراء الرأس 20 ألاف جنيه، 10 ألاف جنيه قيمة قرض تغذية الرأس.

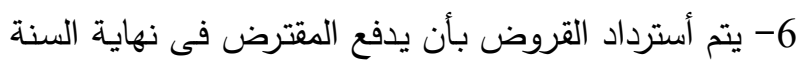
الاولى قيمة قرض التغذية فقط بالاضافة إلى قيمة الفائد المستحقة على كامل القرض بمعدل 14\% بما فية قيمة

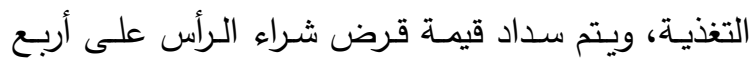

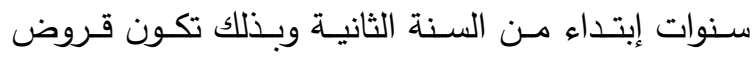

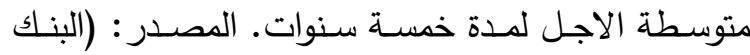

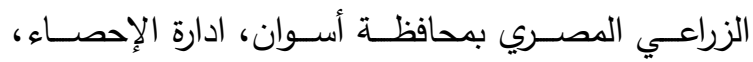

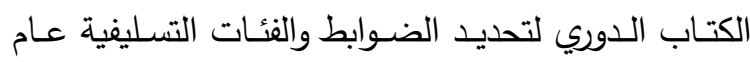
. 2020

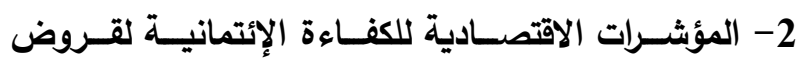

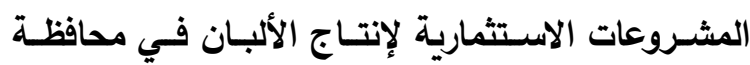

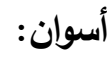

بتضـح مـن بيانـات الجـدول (18) الخــاص بدراســة

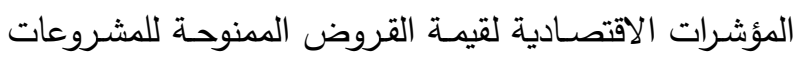

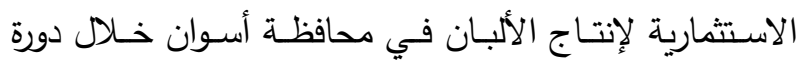
الإنتاج لماشية الفريزيان، والجاموس، والابقارالمحلى الخليط

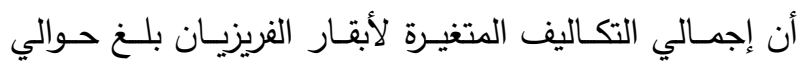

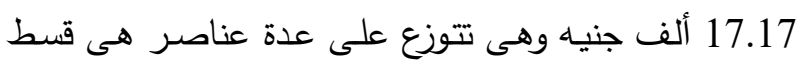

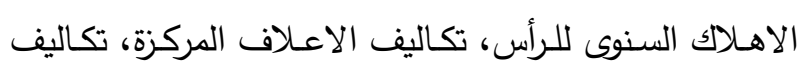

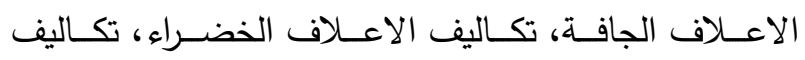

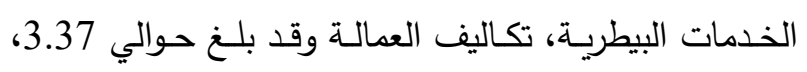

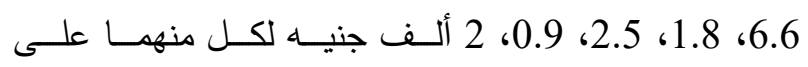

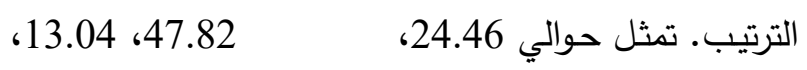
18.11، 6.52، 14.49 \% لكل منها على الترتيب وبلغت

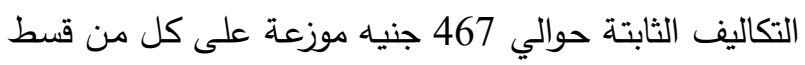

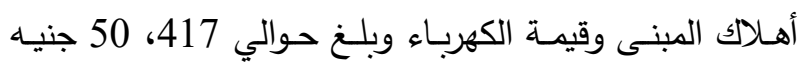
لكل منهمـا على الترتيب تمثل حوالي 89.29، 10.71 \%

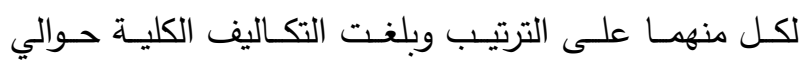
17.64 ألف جنيه، وبلغ قيمة القرض الممنوح للرأس حولي
2005. وقد تبين من المعادلة المقدرة لتطور الاتجاة الزمنى

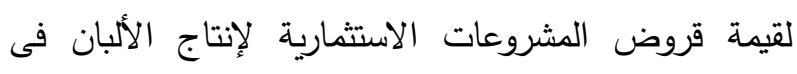

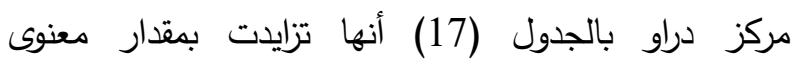

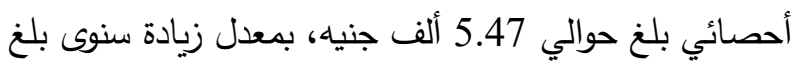
حوالي 10.32\% من متوسط قروض المشروعات الاستثمارية لإنتاج الألبان خلال فترة الدراسة.

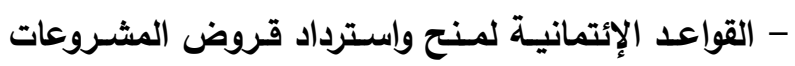
الاستثمارية لإنتاج الألبان في محافظة أسوان:

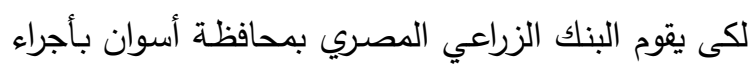

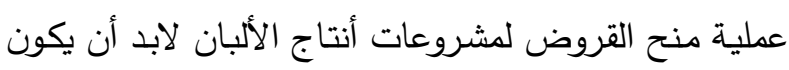

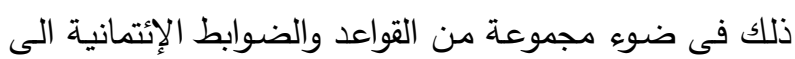

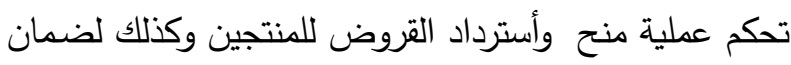
أستراد هذة القروض من الزراع وهذة الضوابط هى:

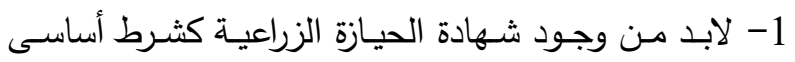

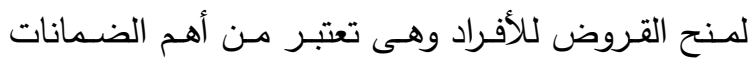
لأسترداد القروض.

2- يتم منح القروض بحد أقصى ثلاث رؤؤس ماشية لإنتاج

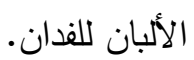

3- تــنح قـروض المشـروعات الاستثمارية لإنتـاج الألبـان

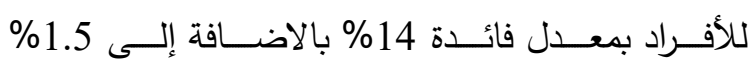

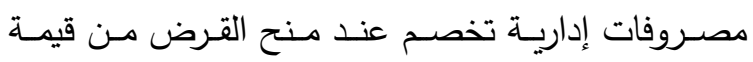

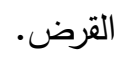

4- تعتبـر قـروض المشـروعات الاسـتمارية لإنتـاج الألبـان قروض متوسطة الاجل تمنح لمدة خمس سنوات سنوات.

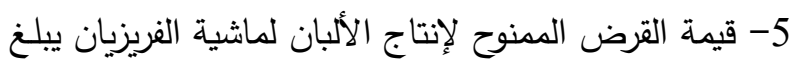

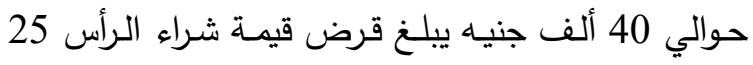
ألف جنيه، 15 ألاف جنيه قيمة قرض تغذية الرأس، قيمة

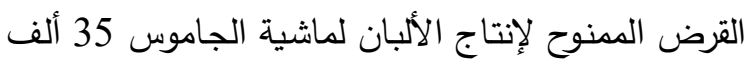
جنيهـ تبلغ قيمة قرض شراء الرأس 20 ألاف جنيه، 15

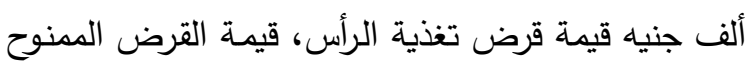

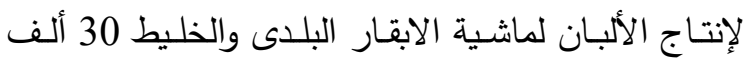


السنوى للرأس، تكاليف الاعلاف المركزة، تكاليف الاعلاف الجافة، تكاليف الاعلاف الخضراء، تكاليف الخدمات

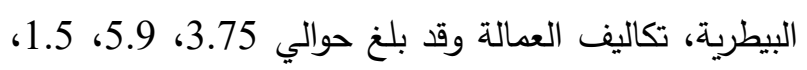

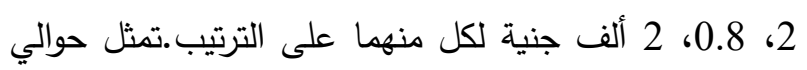
23.5، 23.5، 36.99 ،9.4، 12.53، 5.05، 5.

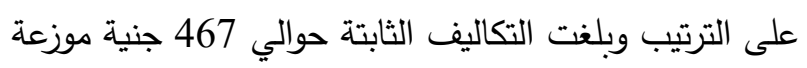
على كل من قسط أهلاك المبنى وقيمة الكهباء وبلغ حوالئ حوالي

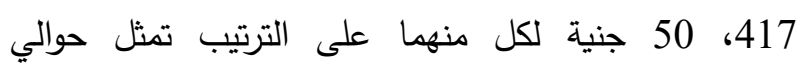
89.29، 10.71 \% لكل منهما على الترتيب وبلغت التكاليف حلفي

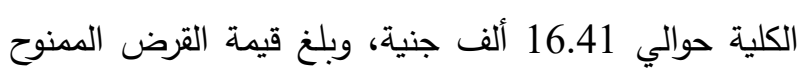

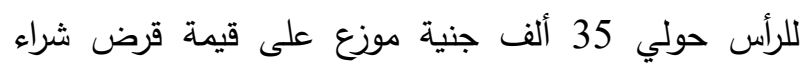

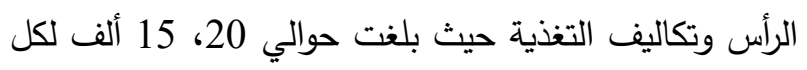

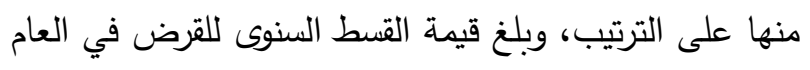
الاول حوالي 15 ألف جنية، ولغ تلنة
40 ألف جنيه موزع على قيمة قرض شراء الرأس وتكاليف

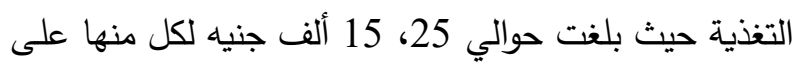

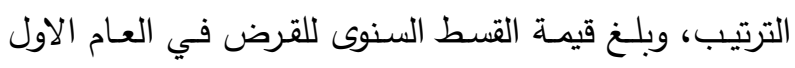

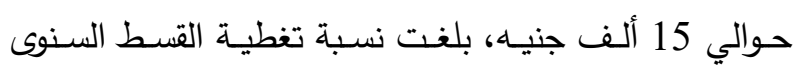

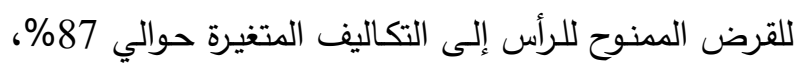

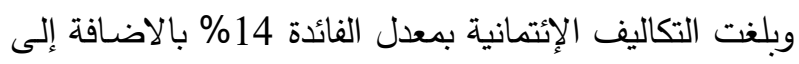

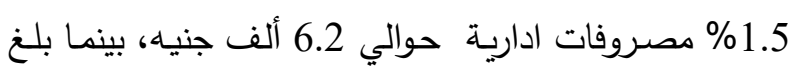

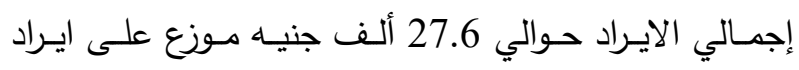

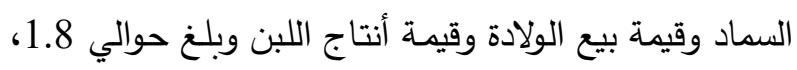

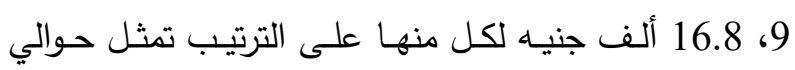

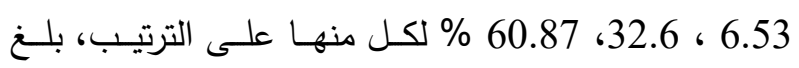
صافي العائد حوالي 11.1 ألف جنيه للرأس. فى حين بلغت التكاليف المتغيرة للجاموس حوالي 15.95

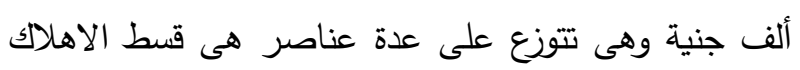

جدول 18. المؤشرات الاقتصادية والإتتمانية للقروض الممنوحة للمشروعات الاستثارية لإنتاج الألبان في محافظة أسوان عام (2021-2020)

\begin{tabular}{|c|c|c|c|c|c|c|c|c|c|}
\hline للفوائد" & إلايرادي & الإنتمالية & التغنية & للمشرو المنورة & 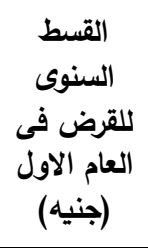 & للقرأس & التكاليف & التكاليف & نوع الماشية \\
\hline 11100 & 26.7 & 6200 & 0.87 & \multirow{3}{*}{1.35} & 15000 & 40000 & 17642 & 17175 & الفريزيان \\
\hline 9950 & 24.8 & 5425 & 0.94 & & 15000 & 35000 & 16417 & 15950 & جاموس \\
\hline 6600 & 18.3 & 4650 & 0.74 & & 10000 & 30000 & 13917 & 13450 & الابقار المحلى والخليط \\
\hline
\end{tabular}

* تم إضافة 1.5 \% من إجمالي قيمة القرض مصروفات ادارية إلى قيمة التكاليف الأتمانية.

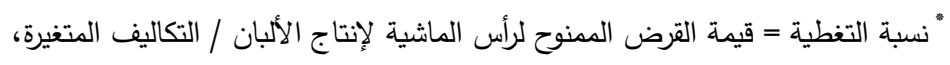
"التكاليف الإنتمانية = القسط السنوى للقرض فى العام الاول * معدل الفائدة. "صافي العائد = إجمالي الايراد - التكاليف الكلية. المصدر : جمعت وحسبت من بيانات: 1- البنك الزراعي المصري بمحافظة أسوان، ادارة الإحصاء، الكتاب الاحصائي الدوري لتحديد الضوابط والفئات التسليفية عام 2020). 2- استبيان عينة الدراسة عام (2020-2021). 3- جدول 16. 
وقيمة أنتاج اللبن وبلغ حوالي 1.5، 7، 9.8 ألف جنيه لكل منها على الترتيب تمثل حوالي 8.2، 38.25، 53.55 \% لكل منها على الترتيب، بلغ صافي العائد حوالي 6.6 ألف كالف جنيه للرأس.

سادسا: دراسة محددات الطلب على القروض المننوحة

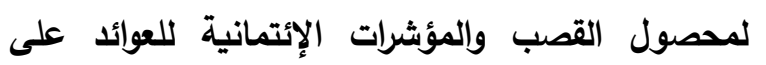
استثمارات القروض في محافظة أسوان.

يتتاول هذا الجزء من البحث دراسة أهم العوامل

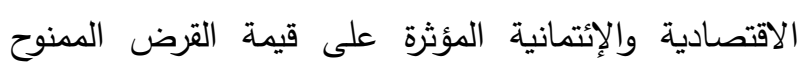
للفان من محصول القصب وكذلك دراسة المؤشرات الإنتمانية للعوائد على الاستثمارات للقروض في محافظة

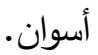

أ- العوامل المحددة للطلب على القروض النباتية المنوحة لمحصول القصب في محافظة أسوان: يتأثر الطلب على القروض النباتية لمحصول القصب في القبل

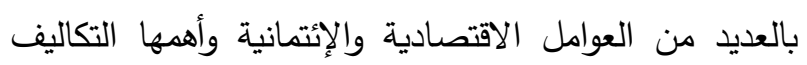

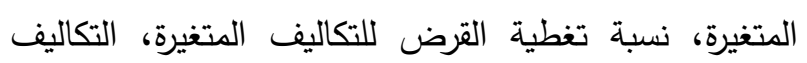

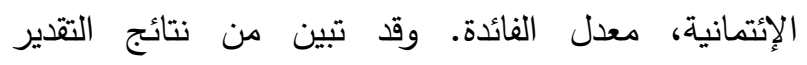

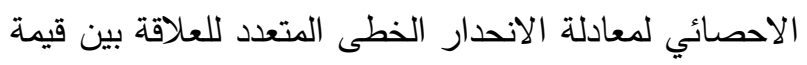
القرض الممنوح للفدان كمتغير تابع للطلب والعوامل المستقلة سالفة الذكر وجود علاقة طردية معنوية أحصائيا بين التكاليف المتغيرة سا، ونسبة تغطية القرض للتكاليف

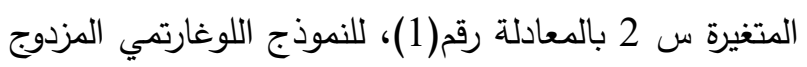

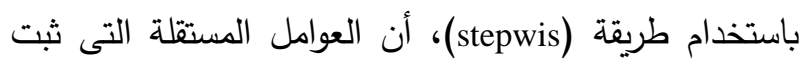

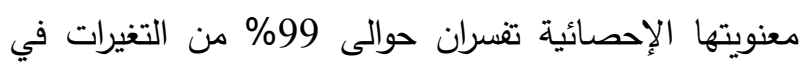
قيمة القروض الفدانية لمحصول القصب، وأنة بزيادة التكاليف المتغيرة، نسبة تغطية القرض للتكاليف المتغيرة بنسبة 10\%

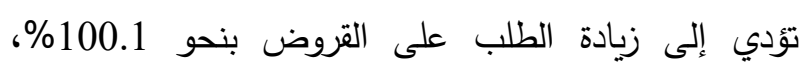

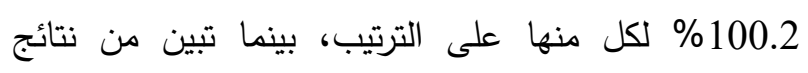

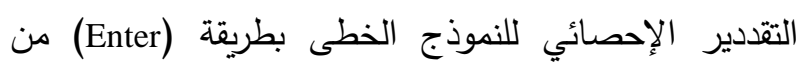

بلغت نسبة تغطية القسط السنوى للقرض الممنوح للرأس إلى الى القي

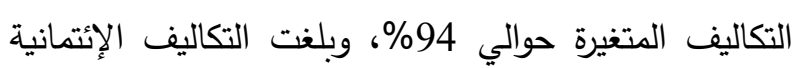

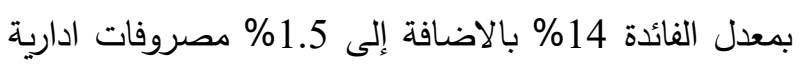

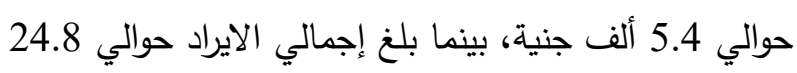
ألف جنية موزع على ايراد السماد وقيمة بيع الولادة وقيمة

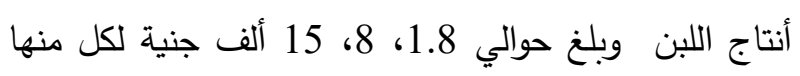

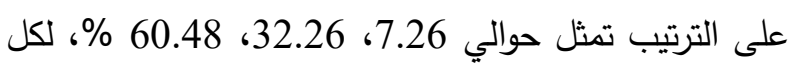
منها على الترتيب، بلغ صافي العائد حوالي 95.95ألف جنية للرأس.

فى حين بلغت التكاليف المتغيرة للابقار المحلى والخليط

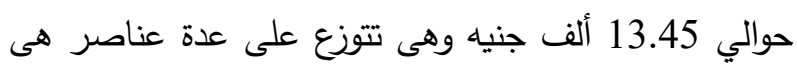
قسط الاهلاك السنوى للرأس، تكاليف الاعلاف المركزة،

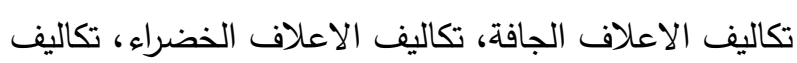

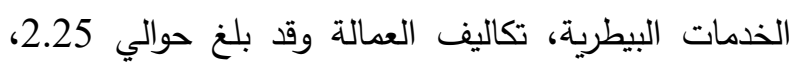

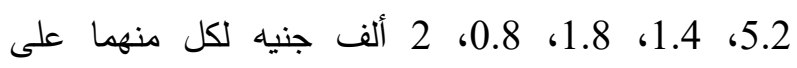
الترتيب.تمثل حوالي، 16.73، 1.4. 1.87، 38.66، 10.81، 10.41، 13.38، 5.95، 14.87 \% لكل منها على الترتيب وبلغت التكاليف 10.41، الثابتة حوالي 467 جنيه موزعة على كل من قسط أهل الهلاك

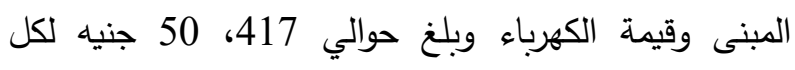

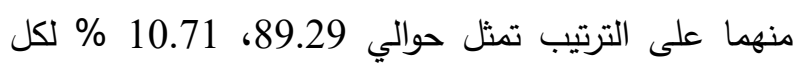
منهما على الترتيب وبلغت التكاليف الكلية حوالي 13.91

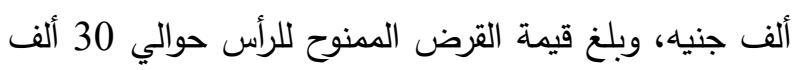
جنيه موزع على قيمة قرض شراء الرأس وتكاليف التغذية حوضية

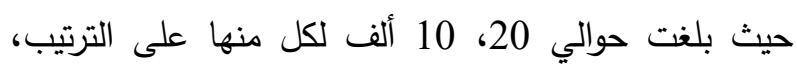
وبلغ قيمة القسط السنوى للقرض في العام الاول حوالي 10

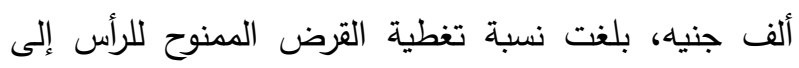

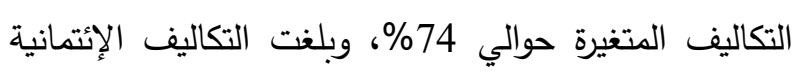

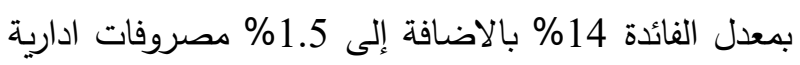
حوالي 4.65 ألف جنيه، بينما بلغ إجمالي الايراد حوالي الئ 18.3 18.3 ألف جنيه موزع على ايراد السماد وقيمة بيع الولادة 
1973 عبد العاطي محمد محمود علي: دراسة إقتصادية لدور البنك الزراعي المصري في تمويل الأنثطة الزراعية ...

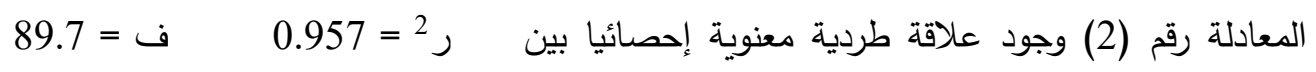

المصدر : جمعت وحسبت من: التحليل الاحصـائي للبيانات

الواردة بالجدول 9.

ب- دراسـة المؤشـرات الإئتمانيـة للعوائـد على الاسـتثمارات للقروض الزراعية في محافظة أسوان:

يتناول هذا الجزء من الدراسة العوائد على الاستثمارات من القروض الزراعية لمحصول القصب ومشروعات أنتاج اللحوم الحمراء ومشروعات أنتاج الألبان فى محافظة أسوان. - محصول القصب: - - مصن

يتضح من البيانات الواردة بالجدول (19) والخاصة بدراسة العوائد على الاستثمارت من القروض الزراعية الممنوحة لمحصول القصب في محافظة أسوان خلا الفتر (2005- 2020). وهذه هي فترة استقرار لسعر الفائدة على قروض محصول القصب حيث بلع معدل الفائدة 5\%وقد بلغ العائد على الجنيه/ قرض حوالي 0.88 جنيه، وقد تبين أنة

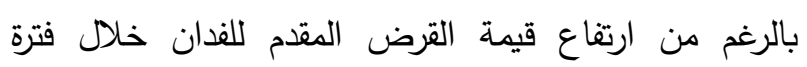

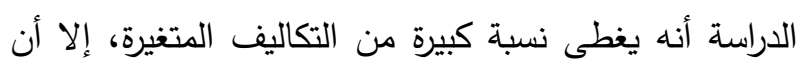
صافي العائد الفداني لم يغطي التكاليف الإنتاجية الكلية بما فيها القرض وفوائدة.
التكاليف المتغيرة س1، نسبة تغطية القرض للتكاليف المتغيرة

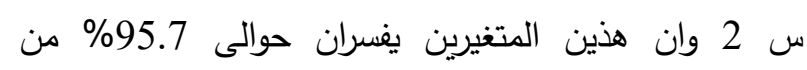
التغيرات في قيمة القروض الفدانية لمحصول القصب وأنة بزيادة التكاليف المتغيرة، نسبة تغطية القرض للتكاليف

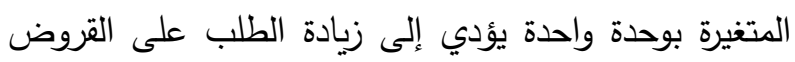
بنحو 0.565 ،3102.72 وحدة على الترتيب، كما تبين وجود علاقة سالبة غير معنوية إحصائيا بين الطلب على القروض والتكاليف الإئتمانية بمعنى زيادة التكاليف الإئتمانية بوحدة واحدة تؤدي إلى انخفاض الطلب على القروض بمقدار 0.16 لو ص ص^=-- 0.013 + 1.001 لو س 1.002 لو س2. معادلة رقم ....... (1) مون

$$
\begin{aligned}
& (82.955)^{* *} \quad(166.337)^{*}(0.250)^{-} \\
& 53730=\text { ف } 0.99=2 \text { ر } \\
& \text { ص^=" - } 0.565 \text { س } 0.4432 .4202 .72 \text { س2 } \\
& 30.16- \\
& \text { معادلة رقم ..................... } \\
& \begin{array}{lll}
(2.1219) \quad(8.489) \quad(0.073-)
\end{array}
\end{aligned}
$$

\begin{tabular}{|c|c|}
\hline محصول القصب & 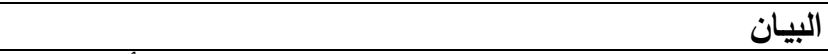 \\
\hline 1.19 & متوسط تكلفة العناصر الإنتاجية التى لم يقدم لها قروض (ألف جنيه) \\
\hline$\% 43.1$ & الأربحية النسبية للمحاصيل التى أخذت قروض\% \\
\hline 0.88 & العائد على الجنيه / قرض(جنيه) \\
\hline
\end{tabular}

جدول 19. العوائد على الاستثمارات مـن القروض النباتيـة الممنوحة لمحصول القصب في محافظة أسـوان خـلال الفترة (2020-2005)

- متوسط التكاليف التي لم يقدم لها قروض = متوسط التكاليف المتغيرة - متوسط قيمة القرض للفدان - الأربحية النسبية للفدان = متوسط صافي العائد للفدان / متوسط التكاليف الكلية *00 - العائد على الجنيه المستثر / قرض = متوسط قيمة القرض للفدان مضافا إلية متوسط التكاليف الإئتمانية / متوسط التكاليف المتغيرة للفدان. المصدر : جمعت وحسبت من بيانات: الجدول 9. 
القرض المقدم للرأس أنه يغطى نسبة كبيرة من التكاليف

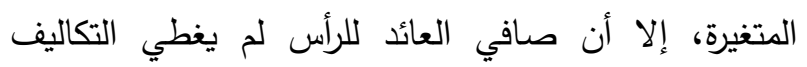
الإنتاجية الكلية بما فيها القرض.

سابعا: دراسة مخاطر الإنتمان النباتي في محافظة أسوان والمشكلات التى تواجه المزارعين والمنتجين والحلول المقترحة في محافظة أسوان: يتاول هذا الجزء من البحث دراسة مخاطر الإتتمان النباتى لدحصول القصب في محافظة أسوان والمشكلات

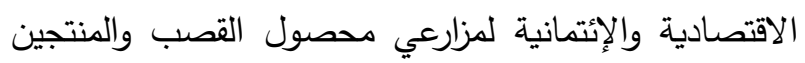
لكشروعات أنتاج اللحوم الحمراء والألبان في محافظة أسوان. أ- مخاطر الإتتمان الزراعي لمحصول القصب في محافظة

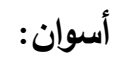

تتحدد القدرة المالية للمزارع على أساس نسبة رأس المال

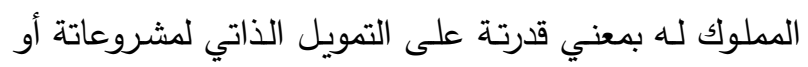

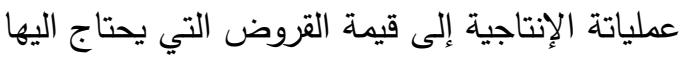

- مشروعات أنتاج اللحوم الحمراء والالبان: يتضح من البيانات الواردة بالجدول(20) بدراسة العوائد على الاستثمارت من القروض الزراعية المنوحة لإنتاج اللحوم الحمراء في محافظة أسوان خلال عامى (2020-

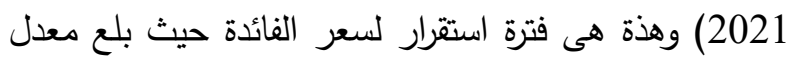

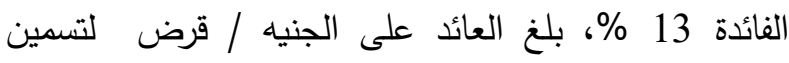
ماشية الفريزيان، الخليط، البلدى حوالي 0.93، 0.86، 1.04 جنيه، وقد تبين أنة بالرغم من ارتفاع قيمة القرض المقدم للرأس أنه يغطى نسبة كبيرة من التكاليف المتغيرة، إلا أن

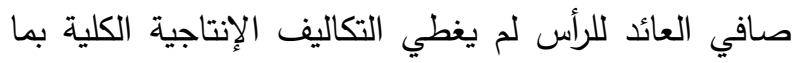

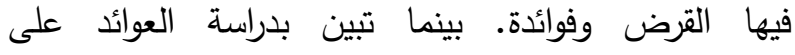
الاستثمارت من القروض الزراعية المنوحة لإنتاج الألبان في لإنيان

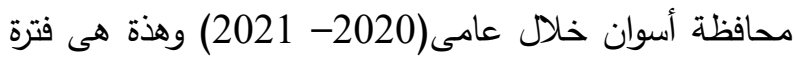
استقرار لسعر الفائدة على لتروض حيث بلع معدل الفائدة

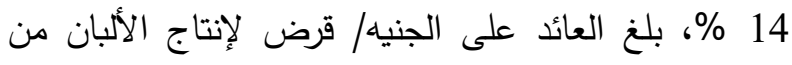

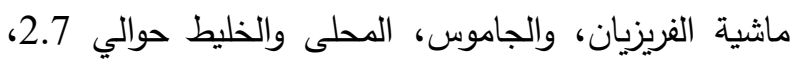

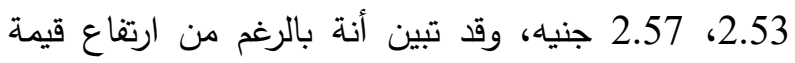

جدول 20. مقارنـة العوائد على الاستثمارات من القروض الممنوحة لمشروعات أنتاج اللحوم الحمراء والألبان من البنك الززاعي المصري فى محافظة أسوان(2005- 2021)

\begin{tabular}{|c|c|c|c|c|}
\hline البلدى & الخليط & الفربزيان & البيان & النشاط الإنتاجى \\
\hline 1.5 & 4.8 & 4.6 & \multirow{3}{*}{ 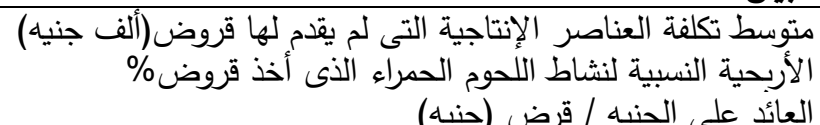 } & \multirow{4}{*}{ أنتاج اللحوم } \\
\hline$\% 39.7$ & $\% 47.4$ & $\% 44.8$ & & \\
\hline 1.04 & 0.87 & 0.93 & & \\
\hline المحلى & الجاموس & الفربزيان & البيان & \\
\hline 3.4 & 19 & 22.8 & \multirow{3}{*}{ 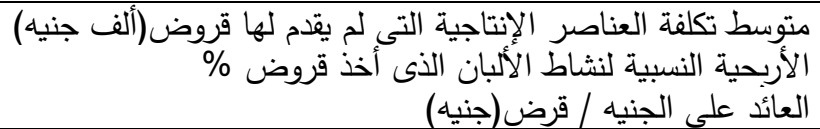 } & \multirow[t]{3}{*}{ أنتاج الألبان } \\
\hline$\% 0.47$ & $\% 60.6$ & $\% 62.9$ & & \\
\hline 2.57 & 2.53 & 2.7 & & \\
\hline
\end{tabular}

- متوسط التكاليف التى لم يقدم لها قروض = متوسط التكاليف المتغيرة - متوسط قيمة القرض الممنوح لرأس الماشية (التسمين أو الالبان). - الأربحية النسبية لرأس الماشية (التسمين أو الألبان) = متوسط صافي العائد لرأس الماشية / متوسط التكاليف الكلية.

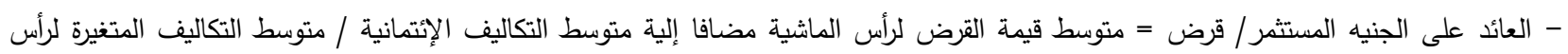
الماشية. 
وهذا يعني أنه كلما زادت نسبة رأس المال المملوك للمزارع أو قيمة موجبة وهو ما يشير إلى أرتفاع الكفاءة الإتتمانية لمحصول القصب.

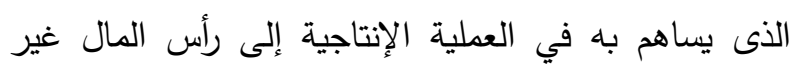
ب- المشكلات الاقتصادية والإتتمانية التى تواجه المزارعين المملوك لة أي المقترض كلما انخفضت درجة المخاطرة

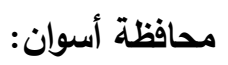
المالية للمزارع، وكلما زاد معدل العائد على رأس المال يتضح من البيانات الواردة بالجدول (22) أنة بدراسة

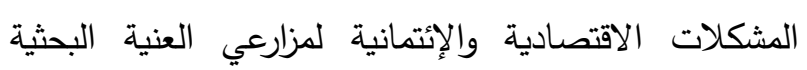
مجتمعة في محافظة أسوان والبالغ عددها 95 مزارع ـ تبين أن مشكلة ضرورة وجود الحيازة الزراعية كثرط وضمان أساسي للحصول على القرض، عدم صرف القروض في وجودي صورة عينية والاكتفاء بالصرف النقدى فقط،، عدم صرف القروض الا بعد سداد القروض السابقة والمستحقة السداد في المرتبة الأولي بنسبة 94.7\%، وجاء في المرتبة الثانية مشكلة طلب عمل استعلام لدي البنك المركزى عن صاحب القرض بنسبة88\%، جاء في المرتبة الثالثة مشكلات تعقيد الثروط والاجراءات للحصول على القرض وكثرة الضمانات، عدم كفاية قيمة القرض للنشاط الإنتاجى المقرر عملة بنسبة 81\%، جاء في المرتبة الرابعة ارتفاع معدل الفائدة على إلى القرض أكثر من 5\% بنسبة 77\%، وجاء فى المرتبة الخامسة مشكلات زيادة عدد مرات التردد على فرع البنك لإنهاء أجراءات صرف القرض، تحصيل القروض السابق منحها بدون النظر لمواعيد حصاد المحاصيل وتسويق المنتجات بنسبة 75\%، وجاء في المرتبة السادسة مشكلة المستثر عن تكلفة رأس المال غير المملوك كلما زاد الربح الناتج من أستعمال القدرة المالية في صورة مدخلات اضافية

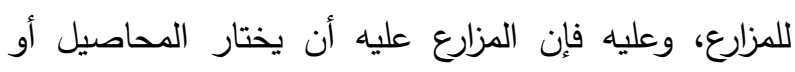
الإنتجة الزراعية التي يكون لها أقل قدر من المخاطرة لكل جنيه من صافي العائد المتوقع، ويعتبر أحد أهم الأساليب لتجنب أكبر قدر من المخاطرة المتوقعة هو الانحراف ولتئ

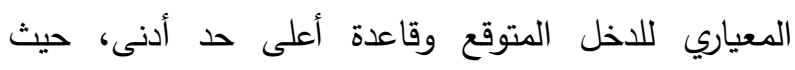
تستخدم هذة القاعدة لإي محصول بطرح ضعف الانحراف المعياري لصافي العائد الفداني للمحصول من متوسطه الحسابي، بذلك فإن المزارع سوف يتخذ قراره باختيار المحصول الأعلى في الحد الأدنى والذي يتسم بأقل مخاطرة

محتملة. وقد تبين من بيانات الجدول (21) أن متوسط صافي العائد الفداني لمحصول القصب في محافظة أسوان خلال الفترة (2020-2021) بلغ حوالي5.75 ألف جنيه، أن الانحراف المعياري لصافي العائد الفداني لمحصول القصب بلغ حوالي 3.33 ألف جنيه، كما تيين أن القيمة المحسوبة لأعلى حد أدنى بلغت حوالي 6.671 ألف جنيه للفذان وهى

عدم صرف القروض فى الموعد المحدد لهبنسبة 65\%،

جدول 21. المؤشرات الاقتصادية لقياس درجة المخاطرة المالية لقروض محصول القصب في محافظة أسوان خلال الفترة (2021-2020)

\begin{tabular}{|c|c|c|c|}
\hline أعلى حد أدنى" & الانحراف المعياري لصافي العائد الفداني & متوسط صافي العائد الفذاني لمحصول & النشاط الإنتاجى \\
\hline 6671 & 3335.85 & 5759 & أنتاج محصول القصب \\
\hline
\end{tabular}

أعلى حد أدنى= 2 * الانحراف المعياري لصافي العائد الفداني لمحصول القصب. المصدر : جمعت وحسبت من : بيانات الجدول 9. 
جدول 22. المشكلات الاقتصادية والإنتمانية التى تواجه المزارعين والمنتجين في محافظة أسوان عام (2020-2021)

\begin{tabular}{|c|c|c|c|}
\hline$\%$ & 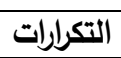 & المشكلات & م \\
\hline 94.7 & 90 & ضرورة وجود الحيازة الزراعية كشرط وضمان أساسى للحصول على القرض. & 1 \\
\hline 94.7 & 90 & عدم صرف القروض في صورة عينية والاكتفاء بالصرف النقدى فقط. & 2 \\
\hline 94.7 & 90 & عدم صرف القروض فى "إلا بعد سداد القروض السابقة والمستحقة السداد. & 3 \\
\hline 92.6 & 88 & طلب عمل استعلام لدى البنك المركزى عن صاحب القرض. & 4 \\
\hline 85.3 & 81 & تعقيد الشروط والاجراءات للحصول على القرض وكثرة الضمانات. & 5 \\
\hline 85.3 & 81 & عدم كفاية قيمة القرض للنشاط الانتاجى المقرر عملة. & 6 \\
\hline 81.1 & 77 & ارتفاع معدل الفائدة على القرض أكثر من 5\%. & 7 \\
\hline 78.9 & 75 & زيادة عدد مرات التردد على فرع البنك لإنهاء أجراءات صرف القرض. & 8 \\
\hline 78.9 & 75 & تحصيل القروض السابق منحها بدون النظر لـواعيد حصاد الدحاصيا وتسويق المنتجات. & 9 \\
\hline 68.4 & 65 & عدم صرف القروض فى الموعد المحدد له. & 10 \\
\hline 63.2 & 60 & عدم تقديم البنك خدمات الية لخدمة المحاصيل. & 11 \\
\hline 57.9 & 55 & تقضيل المزارع صاحب الحيازة الاكبر أثناء صرف القرض. & 12 \\
\hline
\end{tabular}

المصدر : جمعت وحسبت من بيانات : استبيان عينة الدراسة (2020-2021).

العنية البحثية مجتمعة في محافظة أسوان والبالغ عددها 95 مزار

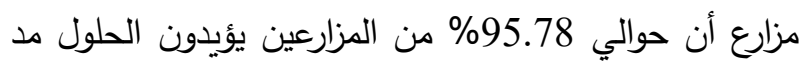

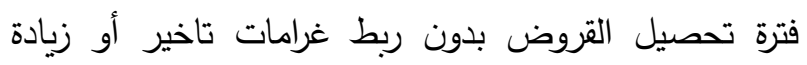
معدل الفائدة واعطا مهلة للزارع المتعثرين فى السداد، مراعاة توافق مواعيد سداد القروض مع مواعيد حصاد المحاصيل

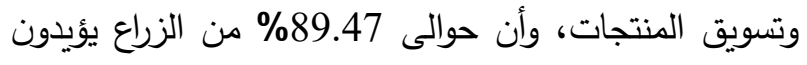
الحلول تقديم وصرف القروض في صورة عينية مثل الاسمدة والتقاوي والمبيدات لضمان جودتها وكفايتها،
وجاء في المرتبة السابعة مشكلة عدم تقديم البنك الى خدمات الية لخدمة المحاصيلبنسبة 60\%، جاء في المرتبة الاخيرة

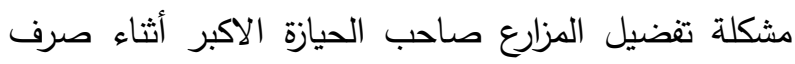
القرض بنسبة 55\%.

ج- الحلول المقترحة للمشكلات الاقتصادية و الإئتمانية التى تواجه المزارعين والمنتجين في محافظة أسوان: يتضح من البيانات الواردة بالجدول(23) أنة بدراسة لهنئ

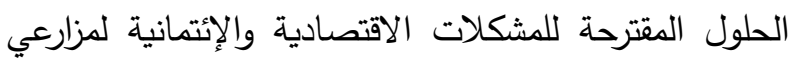

جدول 23. الحلول المقترحة للمثكلات الاقتصادية والإيتمانية التى تواجه المزارعين في محافظة أسوان عام (2020-2021)

\begin{tabular}{|c|c|c|c|}
\hline$\%$ & 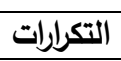 & الحلول & \\
\hline 95.78 & 91 & السدادت. تحصيل القروض بدون ربط غرامات تاخير أو زيادة معدل الفائدة واعطا مهلة المزارع المتعثر فى & \\
\hline 95.78 & 91 & مراعاة توافق مواعيد سداد القروض مع مواعيد حصاد المحاصيل وتسويق المنتجات. & \\
\hline 89.47 & 85 & تقديم وصرف القروض العينية مثل الآسمدة والتقاوى والمبيدات لضمان جودتها وكفايتها & \\
\hline 89.47 & 85 & تعديلزمات الإنتاجة القرض سنويا لكل نشاط انتاجى بما يتوازن مع معدل التضخم السنوى وارتفاع أسعار & \\
\hline 89.47 & 85 & تسهيل اجراءأت صرف وضمانات القروضوالاسرع بعملية صرفها. & \\
\hline 86.32 & 82 & العمل على زيادة قيمة القرض طبقا للنشاط الانتاجى المقرر عملة لتغطية تكاليف الانتاج. & \\
\hline 86.32 & 82 & خفض معدل ألفائدة كصورة من صور الدعم المقدم للمزارع خاصة مشروعات الانتاج. الحيوانى. & \\
\hline 81.05 & 77 & ضرورة صرف القروض طوبلة الاجل لشراء واستصلاح الآراضى. & \\
\hline
\end{tabular}


جابر أحمد بسيونى شحاتة (دكتور) واخرون، أثر تغير السياسات

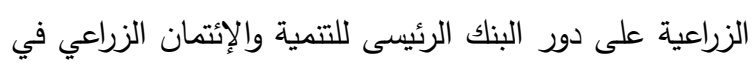

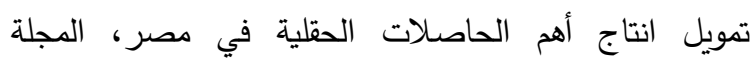

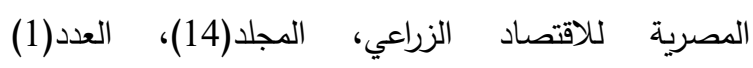

$$
\text { مارس2004. }
$$

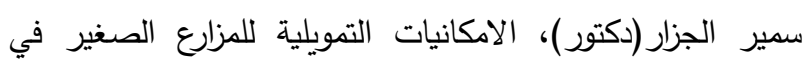

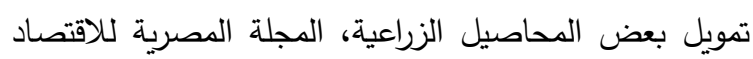
الزراعي، المجلد الثاني والعشرون، العدد الثالث 2012.

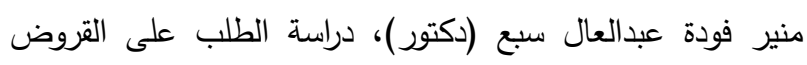

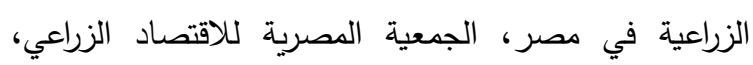

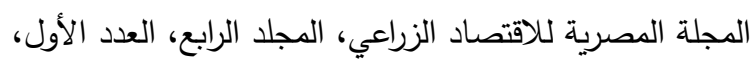

$$
\text { مارس } 1994 .
$$

وزارة الزراعة واستصلاح الاراضي، مديرية الزراعة بمحافظة أسوان،

$$
\text { سجلات ادارة الدحاصيل السكرية(2020-2021). }
$$

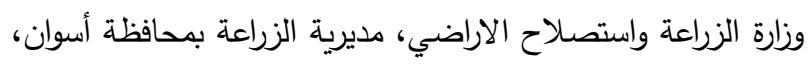

$$
\text { سجلات ادارة الانتاج الحيواني (2020-2021). }
$$

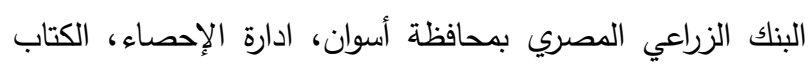

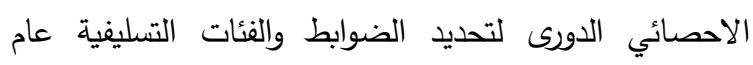

تعديل قيمة القرض سنويا لكل نثاط إنتاجي بما يتوازن مع الانات

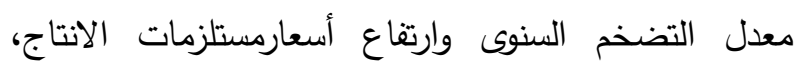

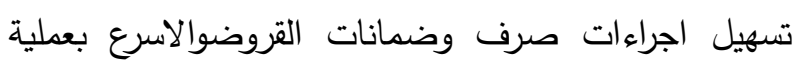

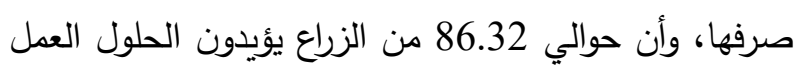

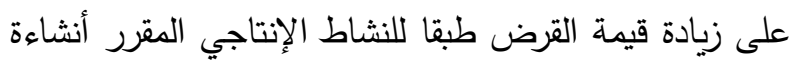

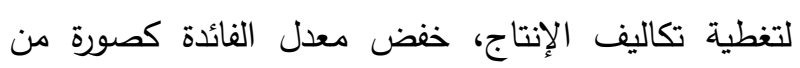
صور الدعم المقدم للزارع خاصة مشروعات الإنتاج الحيواني، وأن حوالي 81.05\% من الزراع يؤيدون الحل

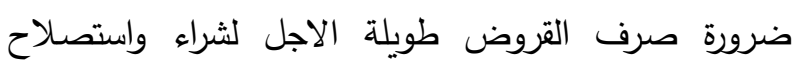

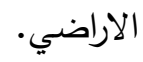

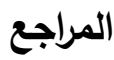

أمين عبدالعزيز منتصر (دكتور) واخرون، دور بنك التتمية

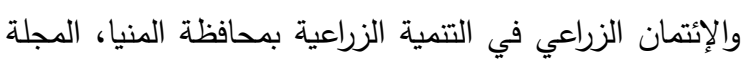

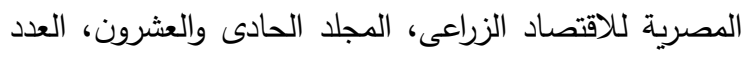

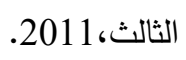




\title{
ABSTRACT \\ An economic Study for the Role of the Egyptian Agricultural Bank to finance Agricultural Activities in Aswan Governorate
}

\author{
Abdel-Aty Mohamed Mahmoud Aly
}

The research aimed to achieve a set of goals in Aswan Governorate during the study period (20052020), which is to study the economic indicators to classify total agricultural loans, the development and efficiency of agricultural credit for each of the plant production loans, red meat production projects, dairy production projects, the most important determinants of demand on agricultural loans for sugarcane crop, agricultural credit risks and problems and proposed solutions to solve them. The method of descriptive and quantitative analysis was used, and the research relied on published and unpublished secondary data for the economic variables of agricultural loans as well as primary data through a random sample selected in Edfu and Kom Ombo destrict and totaled the number of farmers in the research sample is about 95 farms.

The study reached the following results:

1- The annual rate of change of plant loans, investment project loans for red meat production, investment project loans for dairy production, total agricultural loans during the period (2005-2020) amounted to about $0.83,0.44,9.34,1.55 \%$, while the annual average was about $2.65,2.49,0.601$ million pounds. They represent about 46.16, 43.38 and 10.46 percent of the total agricultural loans in Aswan Governorate, which amount to about EGP 5.74 million each, respectively.

2- The annual rate of change of plant loans in the destrict of Edfu, Kom Ombo, Nasr Al Nuba, Daraw during the period (2005-2020) amounted to about $1.54,0.48,0.19,0.76 \%$, while the annual average amounted to about $910,896,468,376$ thousand pounds. They represent about 34.35, 33.8, 17.66, $14.19 \%$ of the total plant loans in Aswan Governorate, which amount to about 2.65 million pounds each, respectively.

3- By studying the economic and credit indicators of plant loans granted to the sugarcane crop in Aswan Governorate during the period (2005-2020) the annual rate of change for each of the variable costs, total costs, the value of the loan granted per feddan, the volume of loans granted to the crop, the percentage of the loan per feddan for variable costs, costs Credit, feddan net return is about 11.21, 11.04, $6.04,0.83,(-5.23), 6.15,9.39 \%$, while the annual average is about $10.07,13.3,8.4$, (2.6 million), 5.7 thousand pounds for each, respectively, while the costs amounted to about the credit is about 420 pounds, and finally, the ratio of loan coverage for variable costs was about $0.84 \%$, and the return on the invested pound was about $88 \%$.

4- The annual rate of change of loans for investment projects to produce red meat in the centers of Edfu, Kom Ombo, Nasr Al Nuba, Daraw during the period (2005-2020) was about $0.39,0.69,(-0.18), 0.36 \%$, while the annual average was about 919, (10.02 million). EGP), 305, 247 thousand EGP, representing about $36.89,40.95,12.25,9.91 \%$ of the total plant loans in Aswan Governorate, which amount to about EGP 2.491 million each, respectively .

5- By studying the economic and credit indicators of the value of loans granted to types of fattening livestock for investment projects for the production of red meat (2020-2021), which are Friesian fattening, mixture, and municipal, the coverage ratio of the value of the loan granted to the head reached about 81,75 and $90 \%$ for each of them, respectively, while The net return is about 11.2, 9.6, and 6.7 thousand pounds per head. The return on the invested pound is about 93,87 , and $1.04 \%$ for each, respectively.

6- The annual rate of change of loans for investment projects for dairy production in the destrict of Edfu, Kom Ombo, Nasr Al Nuba and Daraw during the period (2005-2020) was about 8.73, 10.92, 8.16, $10.32 \%$, while the annual average amounted to 359 , 146, 46, 53 thousand pounds, They represent about $59.73,23.79,7.65$, and $8.81 \%$ of the total plant loans in Aswan Governorate, which amount to about 601 thousand pounds and million pounds each, respectively.

7- By studying the economic and credit indicators of the value of loans granted to types of livestock investment projects for dairy production (20202021), which are Friesian cattle, buffalo, local cows and mixture, the coverage ratio of the value of the loan granted to the head reached about 87, 94, and $74 \%$ for each of them, respectively, while The net return is about 11.1, 9.95, and 6.6 thousand pounds per head. The return on the invested pound is about $2.7,2.53,2.57 \%$ for each, respectively .

8- By studying the factors affecting the demand for loans for the sugarcane crop, it was found that the most important of them are the variable costs, the ratio of the loan coverage to the variable costs, and by using the double logarithmic model, its statistical 
significance was proven at the $1 \%$ probability level during the study period and that these two variables explain about $99 \%$ of the changes in the value of feddan loans for the sugarcane crop, and that by increasing the variable costs, and the coverage ratio by $10 \%$, this leads to an increase in the demand for loans for the sugarcane crop by about $100.1 \%$, $100.2 \%$ for each, respectively, while it was found from the results of the statistical estimation of the linear model that there was a direct statistically significant relationship between the costs changing Q1, the proportion of the loan to cover the costs of changing Q2 and that these two variables explain about $95.7 \%$ of the changes in the value of feddan loans for crop reeds noted that such an increase of variable costs, the proportion of the loan to cover the costs of changing one unit leads to increased demand for loans by about $0.565,3102.72$ units on the arrangement, as it was found that there is a statistically insignificant negative relationship between the demand for loans and credit costs, meaning an increase in credit costs by one unit that leads to Demand for loans decreased by 0.16 units .

9- By studying the economic and credit problems facing farmers in Aswan Governorate, it was found that the most important of them is the necessity of having agricultural tenure as a basic condition and guarantee for obtaining the loan, not disbursing loans in kind and only cash disbursement, not disbursing loans until after paying the previous and due loans, requesting Inquiries were made with the Central Bank about the loan holder, the complexity of the conditions and procedures for obtaining the loan and the large number of guarantees, the insufficient amount of the loan for the productive activity to be used, and it was found that the most important proposed solutions are to extend the loan collection period without attaching delay penalties or increasing the interest rate and giving a deadline to the farmer those in default of payments, taking into account the compatibility of loan repayment dates with the dates of harvesting crops and marketing products, providing and disbursing inkind loans such as fertilizers, seeds and pesticides to ensure their quality and adequacy, adjusting the value of the loan annually for each productive activity in balance with the annual inflation rate and the high prices of production requirements

Keywords: Egyptian Agricultural Bank 'Aswan، plant production، red meat. 